JOURNAL OF GEOPHYSICAL RESEARCH, VOL. 93, NO. B10, PAGES 11,985-12, 008, OCTOBER 10, 1988

\title{
SOMALI BASIN, CHAIN RIDGE, AND ORIGIN OF THE NORTHERN SOMALI BASIN GRAVITY AND GEOID LOW
}

\author{
James R. Cochran
}

\author{
Lamont-Doherty Geological Observatory of Columbia University, Palisades, New York
}

\begin{abstract}
The Northern Somali Basin, located between Chain Ridge and the Horn of Africa north of $4^{\circ} \mathrm{N}$, is characterized by a distinct $5-\mathrm{m}$ geoid low and by large negative gravity anomalies. The boundaries of the basin are marked by steep gradients in both gravity and geoid. Basement in Northern Somali Basin is 1-2 km deeper than on the Carlsberg Ridge flank to the southeast or on the Sheba Ridge flank to the north with a sharp discontinuity across the boundary of the basin. The Western Somali Basin, to the south, was created in the Late Jurassic and Early Cretaceous by the movement of Madagascar away from Africa. Reinterpretation of the magnetic anomalies in the Western Somali Basin shows that they record both limbs of a mid-ocean ridge that was active by M22 time (Kimmeridgian) and died soon after MO (Aptian). Magnetic and gravity data allow the relict ridge crest to be traced from Davie Ridge near the African coast to the Dhow-VLCC-ARS fracture zone complex at $50^{\circ} \mathrm{E}$. Davie Ridge is a transform fault connecting the Western Somali Basin spreading center with a similar age spreading center in the Mozambique Basin. The Dhow-VLCC-ARS complex can be shown to continue north of the $4^{\circ} \mathrm{N}$ bathymetric high separating the Northern and Westem Somali Basins and to intersect the African margin near $7^{\circ} \mathrm{N}$. The Northern Somali Basin thus appears to be the third of a series of oceanic basins separated by long transform faults created during movement between East and West Gondwanaland. The original Northern Somali Basin was split apart by the northward motion of India in the Late Cretaceous and Chain Ridge formed along the new boundary. Thermal and gravity modeling shows that the flexure resulting from differential subsidence across Chain Ridge combined with the difference in lithospheric thermal structure (Late Jurassic vs. Early Tertiary) on either side of it explains well the amplitude and shape of the observed geoid step and gravity anomalies across Chain Ridge. The geoid step up from the basin up to the African coast can be modeled as an edge effect between the juxtaposed Jurassic oceanic and African continental crust. Thus, the geoid and gravity low over the Northern Somali Basin results from the superposition of a continental edge effect anomaly and the fracture zone edge effect anomaly.
\end{abstract}

\section{Introduction}

The Northern Somali Basin is a small oceanic basin located east of the Horn of Africa between the African continental margin and Chain Ridge (Figure 1). It is bounded on the north by a submerged spur of the African continent which contains the island of Socotra and by Error Ridge which separates the Northern Somali Basin from Miocene to Recent crust generated at the East Sheba Ridge [Laughton et al., 1970; Cochran, 1981]. The basin is bounded on the south by a broad bathymetric high at $4^{\circ} \mathrm{N}$ which extends from the African continental margin nearly to the southern end of Chain Ridge and separates the Northern and Western Somali Basins.

The Northern Somali Basin has been described by Bunce et al. $[1966,1967]$. They found that it is characterized by a flat abyssal plain morphology underlain by about $2 \mathrm{~s}$ of flat layered sediments. This structure contrasts with that found

Copyright 1.988 by the American Geophysical Union.

Paper number 7B1060.

0148-0227/88/007B-1060\$5.00 east of the Chain Ridge, where the southern flank of the Carlsberg Ridge is characterized by rough bathymetry and much thinner sediments (Figure 2). Bunce et al. [1967] also distinguished between the thickly sedimented Northern Somali Basin and the region to the south where "the rough basement surface is buried beneath relatively thin sediment deposits" [Bunce et al., 1967, p. 2550]. Deep Sea Drilling Project (DSDP) site 234, located in the Northern Somali Basin on a small ridge at $4^{\circ} 29^{\prime} \mathrm{N}$ near the boundary between the Northern and Western Somali Basins, only penetrated $242 \mathrm{~m}$ and bottomed in sediments probably of early Oligocene age [Shipboard Scientific Party, 1974a]. Thus although the thick sediments suggest that it is old, neither the age or origin of the Northern Somali Basin is known, nor is its relationship to the surrounding tectonic elements well understood.

The Northern Somali Basin is characterized by large negative gravity anomalies and the boundaries of the basin are marked by steep gradients in the gravity anomalies (Figure 3). Stein and Cochran [1985] observed that there appears to be a change in the regional level of the gravity anomalies from about -50 $\mathrm{mGal}$ south of Error Ridge in the Northern Somali Basin to about $0 \mathrm{mGal}$ north of Error Ridge in the eastern Gulf of Aden. Similarly, geoid profiles across the basin (Figure 4) show that its boundaries are associated with steep gradients so that the Northern Somali Basin appears as a distinct 5-m depression in the geoid.

The purpose of this study is to use geophysical data to determine the origin of the Northern Somali Basin and its relationship to surrounding tectonic elements. This will involve a reexamination of the magnetic anomalies in the Western Somali Basin to the south. We will then investigate the nature and cause of the Somali Basin gravity and geoid low and propose an explanation for it.

\section{Geological Setting of the Somali Basin}

The Northern Somali Basin is one of a series of small basins making up the western margin of the Indian Ocean along the coasts of Africa and Arabia. These basins are isolated from the rest of the Indian Ocean by major bathymetric features and only the Mozambique Basin, between Madagascar and Africa, can be shown to have an origin through seafloor spreading at the present system of mid-ocean ridges. Segoufin [1978] and Simpson et al. [1979] identified magnetic anomalies M22-M0 (Kimmeridgian-Aptian) in the Mozambique Basin between $22^{\circ} \mathrm{S}$ and $27^{\circ} \mathrm{S}$. The Mozambique Basin magnetic anomalies appear continuous with anomalies 34-0 (Campanian-Recent) centered on the active Southwest Indian Ridge which were identified further south by Bergh and Norton [1976]. These anomalies thus document the formation of the Mozambique Basin by the motion of Antarctica away from Africa beginning in the Late Jurassic.

Mesozoic magnetic anomalies have also been identified in the Western Somali Basin by Segoufin and Patriat [1980] and by Rabinowitz et al. [1983]. These anomalies trend east-west and were interpreted as documenting both limbs of a now defunct spreading center which formed the Western Somali Basin as Madagascar and India moved southwards away from Africa. The anomaly sequence was identified as M0-M22 by Segoufin and Patriat [1980] and as M10 to M25 by Rabinowitz et al. [1983]. One reason for the different interpretations is that the thick sediments in the Western Somali Basin [Coffin et al., 1986] prevent direct observation of an extinct ridge axis and 


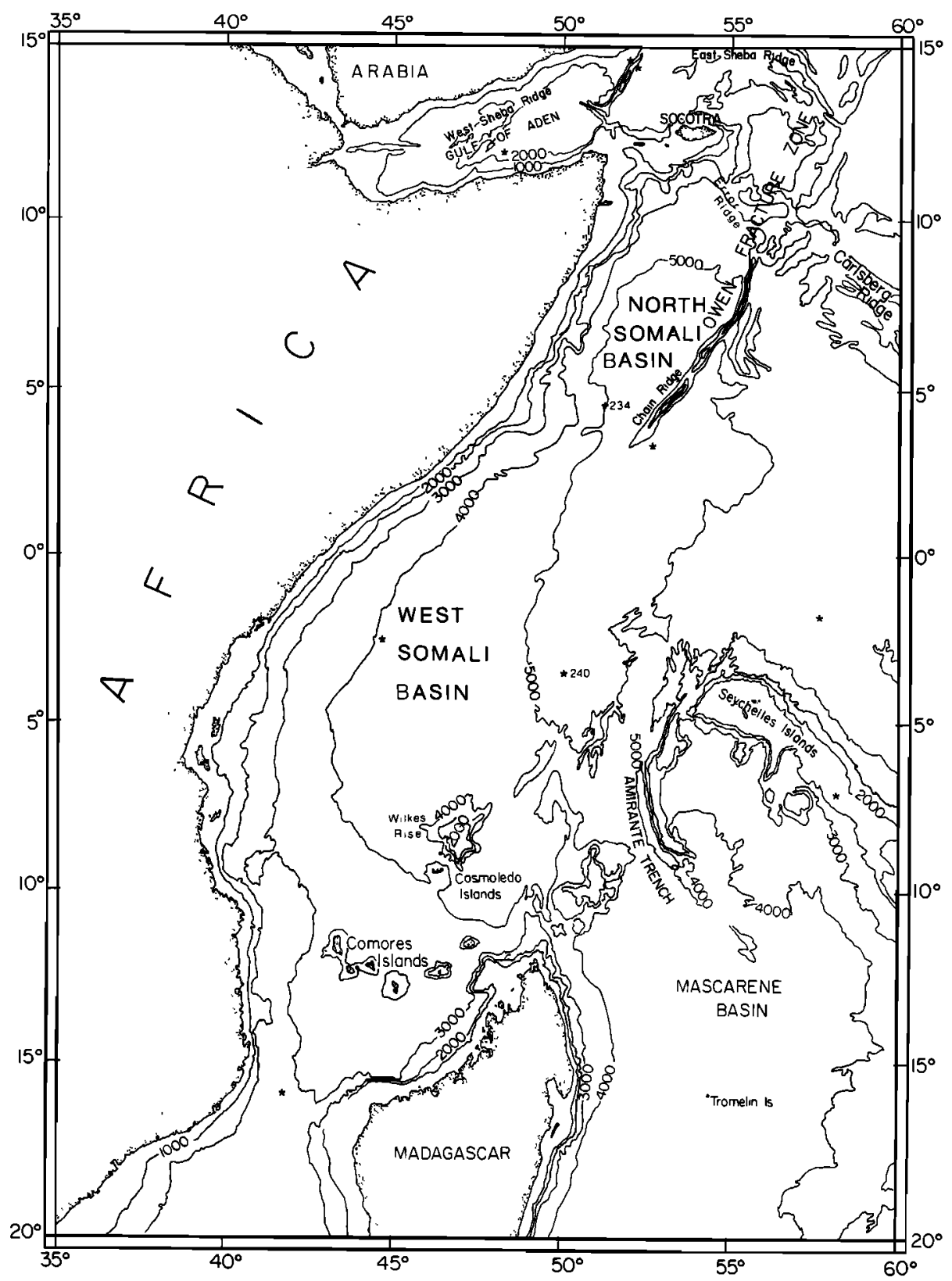

Fig 1. Bathymetric map of the western Indian Ocean showing the location of features discussed in the text. Stars show locations of DSDP drill sites. Bathymetry is simplied from Canadian Hydrographic Service [1975] charts.

identification of the anomalies depends on recognition of a symmetry axis in the magnetic anomalies. The ridge axis location proposed by Segoufin and Patriat [1980] is approximately 150 to $200 \mathrm{~km}$ north of that proposed by Rabinowitz et al. [1983].

Parson et al. [1982] in an abstract also reported the presence of anomalies M2-M22 in the Somali Basin. Masson et al. [1982] and Masson [1984] later presented maps showing magnetic lineations that they stated were from Parson et al. [1982]. However, the data on which they are based has not been published and they thus cannot be evaluated.

A reinterpretation of the data utilized by Rabinowitz et al. [1983] is shown in Figure 5. The new interpretation essentially agrees with that of Segoufin and Patriat [1980] in both anomaly identifications and spreading rates. The new anomaly identification is compared with that of Rabinowitz et al. [1983] for each profile in Figure 6. On a number of profiles, the two studies basically agree on the identification of anomalies M10-M13 on the southern flank. The differences between the two interpretations arise from the fact that Rabinowitz et al. [1983] place the extinct ridge axis in the center of a sequence of relatively short wavelength anomalies to the north of M10. On the other hand, I identify these anomalies as the entire sequence of lower amplitude, short wavelength anomalies between M6 and M10. This latter correlation appears to be confirmed by the presence of a distinctive and diagnostic anomaly M4 in its appropriate location (Figures 5 and 6). On the northern flank, the sequence from M3 to M7 is particularly clear and constrains the location of the extinct ridge axis. The Somali Basin spreading center appears to have died shortly after M0 time, at about 102.5 m.y. B.P. according to the Larson and Hilde [1975] time scale or about $112-113$ m.y. B.P. according to the more recent Harland et al [1982] and Kent and Gradstein 


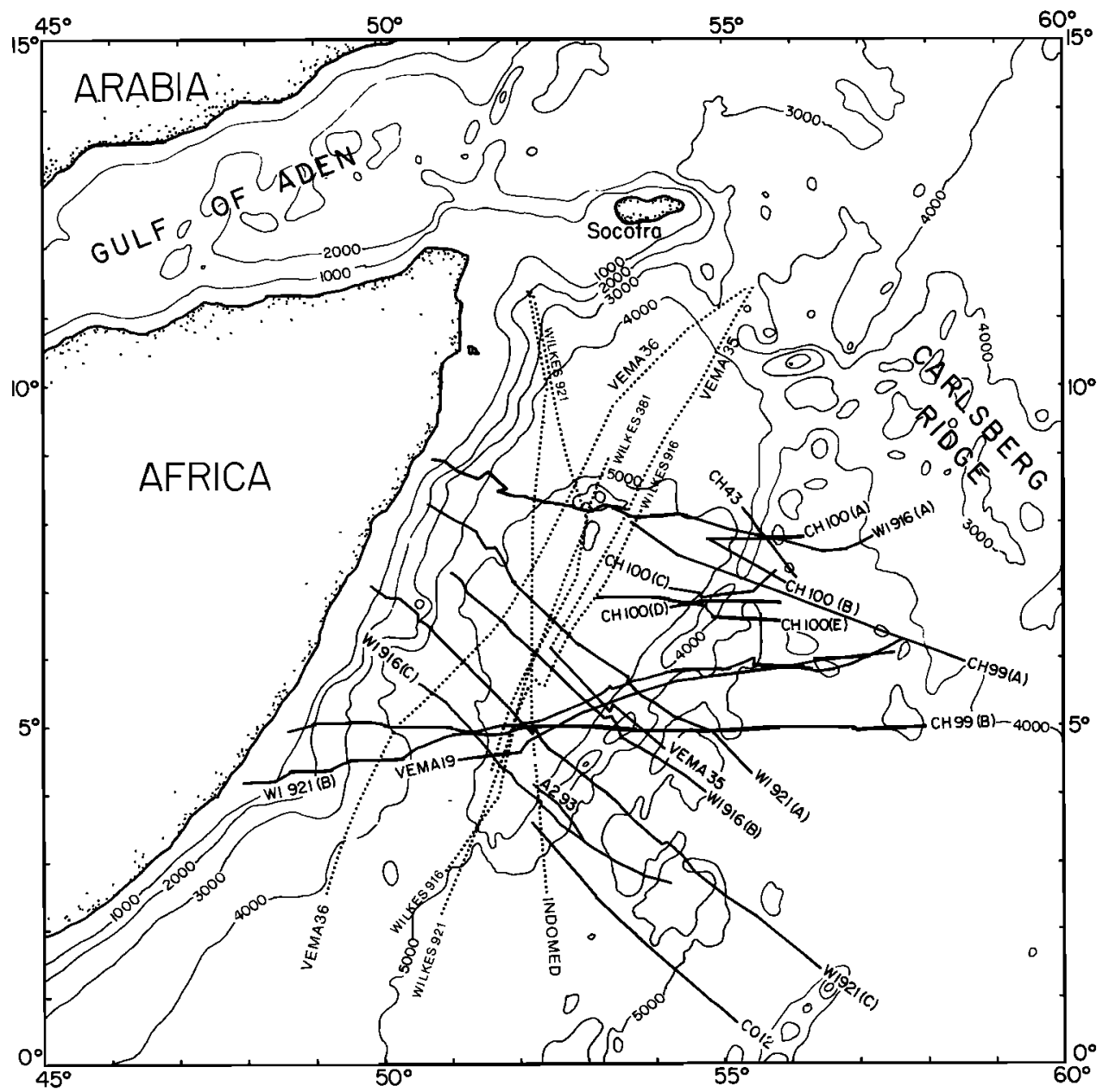

Fig 2a. Location of ship tracks for profiles across the Northern Somali Basin. Track identification corresponds to those on the profiles. Solid lines show location of profiles in Figure $2 \mathrm{~b}$ and dotted lines location of profiles in Figure 14.

[1985] timescales. The anomaly correlation shown in Figure 5 is further supported by the observation that the proposed relict ridge axis is the location of a free-air gravity anomaly low on each profile (Figure 7) as is often observed over extinct midocean ridges [Watts, 1982; Weissel and Watts, 1979; Talwani and Eldholm, 1977; Kristoffersen and Talwani, 1977].

Coffin and Rabinowitz [1987] state that the anomaly identifications of Rabinowitz et al. [1983] are more convincing because they were able to identify magnetic anomalies on a Glomar Challanger 25 line across the Western Somali Basin at $42^{\circ} \mathrm{E}-43^{\circ} \mathrm{E}$ which Segoufin and Patriat [1980] considered to be disturbed by fracture zones. However, the depth to basement map presented by Coffin and Rabinowitz [1987] shows four large north-south ridges located between $42^{\circ} \mathrm{E}$ and $43^{\circ} \mathrm{E}$ which could be interpretated as a series of closely spaced fracture zones (Figure 8). The locations at which the Glomar Challanger line crosses these ridges and another fracture zone which we identify near $43^{\circ} \mathrm{E}$ are shown in Figure 6 along with the anomaly identifications of Rabinowitz et al. [1983]. No correlations are shown between the observed data and our model for that line because it does not appear to us that the anomalies can be convincingly identified using either our model or that of Rabinowitz et al. [1983].

The spreading center in the Western Somali Basin was active by M22 time and is contemporary with the spreading center in the Mozambique Basin. The two spreading centers are linked by the Davie Ridge, a nearly 2000 -km-long transform fault which originally in large part cut through continental crust
[Scrutton, 1978; Scrutton et al., 1981]. The Western Somali Basin mid-ocean ridge was abandoned shortly after M0 time (Aptian) following the development of seafloor spreading between Madagascar/India and Antarctica/Australia.

The magnetic anomaly pattern, relict ridge crest, and fracture zones in the Western Somali Basin are shown in Figure 8. The fracture zone location is based primarily on disruptions of the magnetic anomaly sequence and to a lesser extent on seismic reflection and gravity data. The large offset fracture zone at $47^{\circ} \mathrm{E}$ is a particularly prominent gravity feature and can be traced north to $1^{\circ} \mathrm{N}$ on the basis of gravity anomalies. All of the fracture zones were identified on more than one track.

The three westernmost of the fracture zones identified on Figure 8 appear to continue directly into islands of the Comoro group. In addition, the north-south trend of the fracture zones is a prominent trend for fissures and topographic lineations in the Comoros [Esson et al., 1970]. The Comoros are young volcanic islands created at a hot spot presently located under Grand Comore, which has active volcanism [Emerick and Duncan, 1982]. It appears as if the hot spot utilized the Mesozoic fracture zones to define the locations at which large volcanic features would be constructed.

A similar suggestion was made by Mauge et al. [1982] based on the fracture zones identified by Ségoufin and Patriat [1980]. However, the correspondence is much more compelling with our slightly different placement of fracture zones. In addition, the major $47^{\circ} \mathrm{E}$ fracture zone runs up the axis of the Wilkes Rise, while the two other fracture zones that 


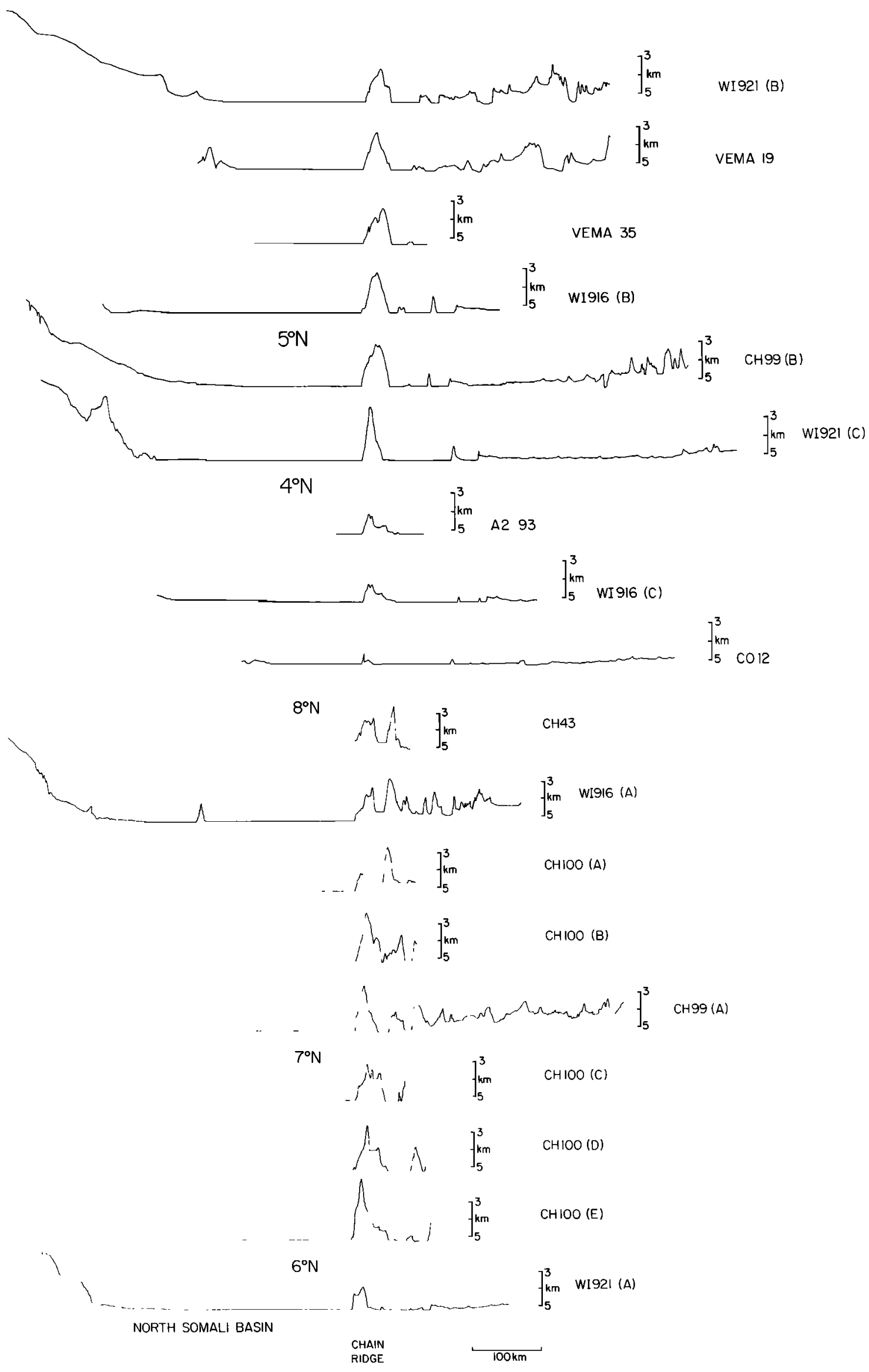

Fig 2b. Bathymetry profiles across the Northern Somali Basin and Chain Ridge. Location of profiles is shown in Figure $2 \mathrm{a}$. All profiles have been projected along $\mathrm{N} 120^{\circ} \mathrm{E}$, perpendicular to Chain Ridge and to the African margin. 


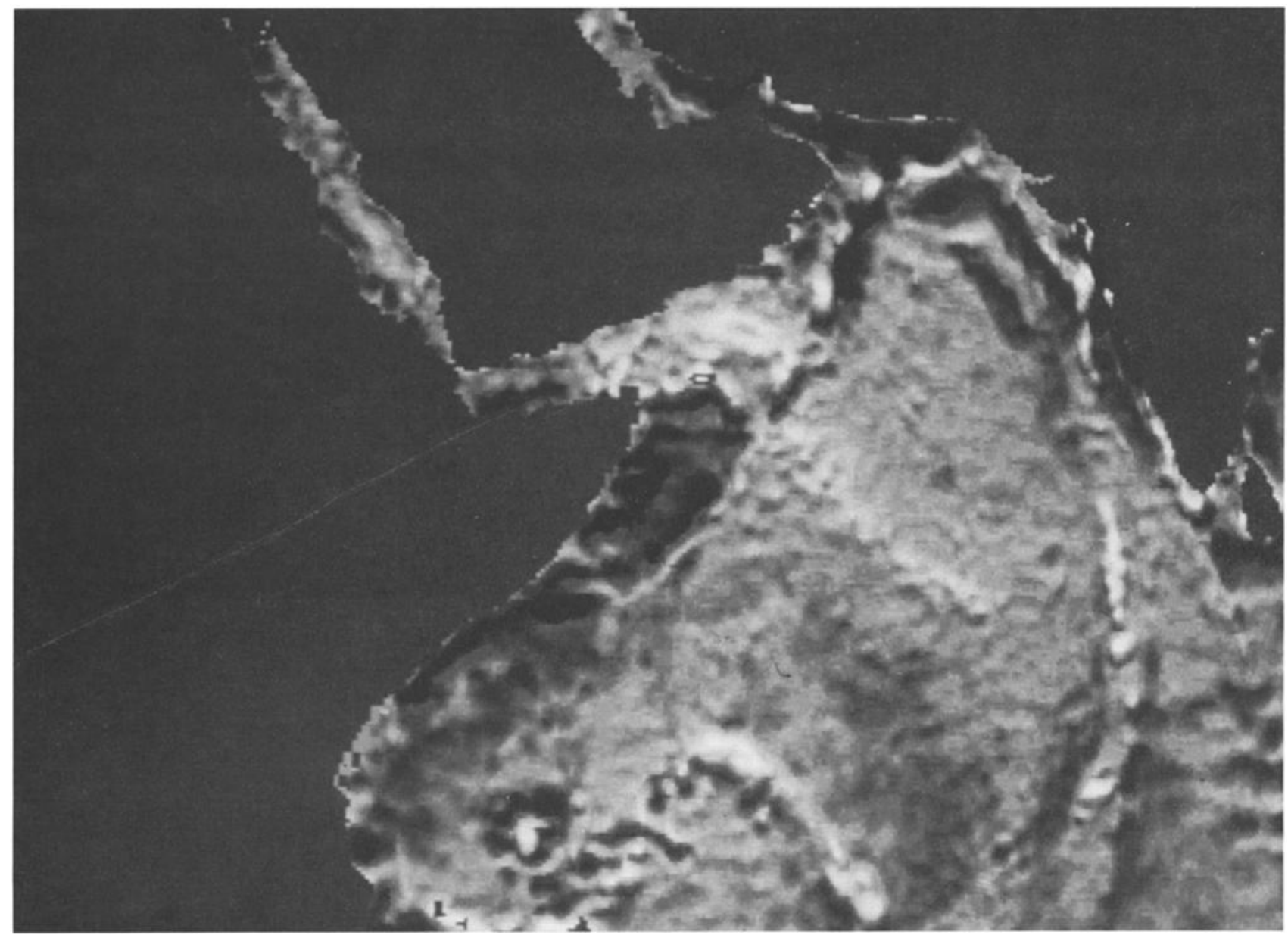

Fig 3. Gray and white image of SEASAT derived gravity anomalies in the Western Indian Ocean. Note prominent negative anomaly over the Northern Somali Basin and sharp gradient at boundaries of the basin.

we identified at $46.2^{\circ} \mathrm{E}$ and $48^{\circ} \mathrm{E}$ continue through Aldabra and Cosmoledo Islands respectively. The fact that the major volcanic and bathymetric features in the southern part of the Somali Basin occur along the fracture zones identified on the basis of the magnetic anomalies lends some confidence to the positions of the fracture zones (which was done without considering the location of the islands).

The Western Somali Basin spreading center can be traced eastwards nearly to the Dhow-VLCC-ARS fracture zone complex identified by Bunce and Molnar [1977]. This set of closely spaced fracture zones is not only a prominent bathymetric feature, forming a series of linear ridges across the otherwise flat basin, but also is a major gravity feature at least as far south as $3^{\circ} \mathrm{S}$ where the Western Somali Basin spreading center intersects the Dhow fracture zone (Figure 9). The fracture zone complex also marks the location of a large regional change in the depth to basement. Schlich et al. [1972] presented a seismic reflection line from the Amirante Ridge at $5^{\circ} \mathrm{S}$ to the African coast near $2^{\circ} \mathrm{S}$. It shows an abrupt change ("une remontee brutale") in basement depth across the Dhow fracture zone at about $3^{\circ} 30^{\prime} S$. Schlich et al. [1972] found that east of the Dhow fracture zone the sediment thickness was always less than $1 \mathrm{~s}$, while immediately to the west, it averaged slightly less than $2 \mathrm{~s}$ and reached a thickness of greater than $2.4 \mathrm{~s}$. Water depths are $5000-5100 \mathrm{~m}$ east of the Dhow fracture zone and about $4800 \mathrm{~m}$ to the west. The $47^{\circ} \mathrm{E}$ fracture zone can also be identified in Schlich et al's [1972] seismic profile as a prominent basement high nearly reaching the sea bottom, but it is not associated with a significant change in basement depth.
The Dhow and VLCC fracture zones thus appear to form a major boundary dividing the Somali Basin into eastern and western portions. The step in basement depths across the fracture zones implies that the eastern section is significantly younger. Masson et al. [1982] and Masson [1984] presented maps showing east-west trending $M$ sequence magnetic anomaly isochrons east of the fracture zone complex, but did not show any data. DSDP site 240 , slightly to the east of the fracture zones (Figure 8) encountered a Mid-ocean ridge basalt (MORB) - type basalt at a depth of $200 \mathrm{~m}$ below sea bottom beneath Paleocene sediments [Shipboard Scientific Party, 1974b]. However, although thick glassy zones suggest that the basalt was erupted at the seafloor, the Shipboard Scientific Party [1974b] stated that the presence of altered, apparently baked chalk fragments raise the possibility that it is a shallow intrusive and not a sample of the oceanic crust. Seismic lines across the drill site were so poor that basement could not be resolved.

The Schlich et al. [1972] seismic reflection line passes close to the relict spreading center betv 'een the Dhow and $47^{\circ} \mathrm{E}$ fracture zones over nearly the youngest crust created at that spreading center. Thus it can be argued that the significantly younger crust east of the Dhow and VLCC fracture zones was not created at an eastward continuation of that spreading center during the Late Jurassic-Early Cretaceous southward motion of India/Madagascar, but rather was created during northward motion of India during the mid- to Late Cretaceous. In fact, it is conceivable that the ancestral Carlsberg Ridge could have formed along the fracture zones in a manner similar to that in which the Galapagos spreading center appears to have formed 


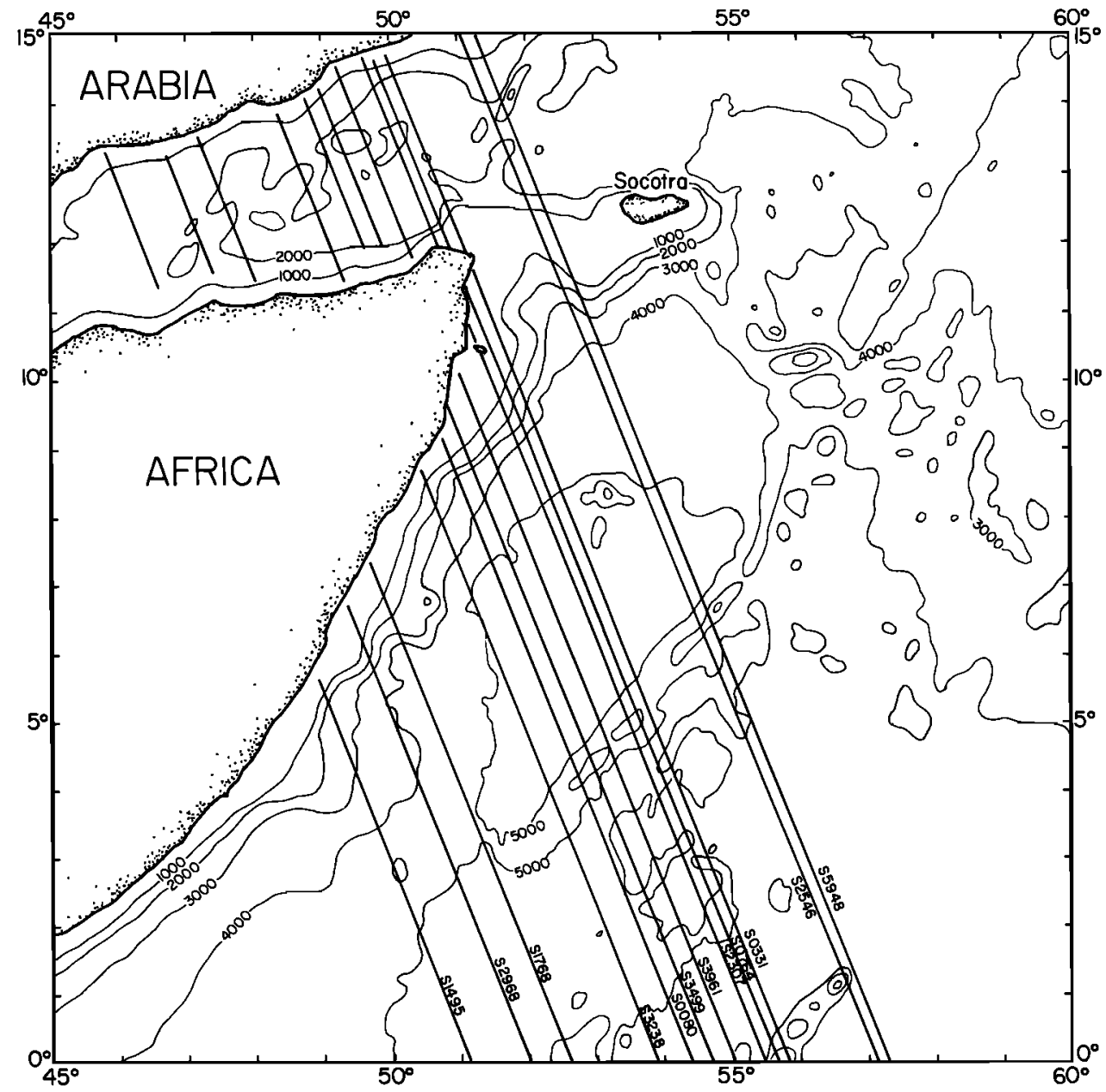

Fig 4a. Location of SEASAT tracks for profiles across the Northern Somali Basin. Track identification corresponds to those on the profiles.

along a Pacific-Farallon fracture zone forming the Grijalva scarp [Rea and Malfait, 1974; Hey, 1977].

Coffin and Rabinowitz [1987] also suggest that the fracture zone complex separates crust to the west created by the southward motion of India/Madagascar from crust to the east created by the northward movement of India. However, they do not regard them as fracture zones, but rather as "relict divergent plate boundaries" and state that they cannot be used to constrain the fit between Africa and Madagascar. However, the fact that they are parallel to the fracture zones within the Somali Basin (Figure 8) and apparently continue into the ARS fracture zone which is located west of Chain Ridge within Early Cretaceous seafloor suggest the Dhow and ARS ridges were originally fracture zones.

\section{Origin of the Northern Somali Basin}

The relationship between the Dhow-VLCC-ARS fracture zone complex and Chain Ridge can be seen in Figure 10. The VLCC fracture zone is quite apparent on the bathymetric map as a north-south trending ridge along $50^{\circ} \mathrm{E}$. It passes west of the southern tip of Chain Ridge and terminates at about $3^{\circ} \mathrm{N}$ near the southeast corner of the bathymetric high that forms the boundary between the Northern and Western Somali Basins. Chain Ridge is greatly reduced in height south of $4^{\circ} \mathrm{N}$ but can be traced as a morphologic feature to $2^{\circ} \mathrm{N}$ about $50 \mathrm{~km}$ east of the VLCC fracture zone. Although there is a slight dis- continuity in the VLCC fracture zone at $2^{\circ} \mathrm{N}$, the two ridges do not appear to be continuous, and the VLCC fracture zone is not a southward continuation of Chain Ridge. The ARS fracture zone is located northwest of the Chain Ridge and can be traced as a continuous feature from $2^{\circ} 40^{\prime} \mathrm{N}$ to $4^{\circ} 15^{\prime} \mathrm{N}$ just east of the $4^{\circ} \mathrm{N}$ topographic high. There is no morphologic continuation of the ARS fracture zone north of $4^{\circ} 15^{\prime} \mathrm{N}$ into the Northern Somali Basin (Figure 11). However, a gravity high encompassing both the ARS fracture zone and a hill to the north of it continues NNW with a relative amplitude of greater than $25 \mathrm{mGal}$ to the African margin near $7^{\circ} \mathrm{N}$ (Figure 12). A seismic reflection line crossing the gravity high at about $5^{\circ} 30^{\prime} \mathrm{N}$ shows that it is associated with a small bathymetric high resulting from a basement peak (Figure 13).

The ARS fracture zone thus appears to continue north of the $4^{\circ} \mathrm{N}$ bathymetric high into the Northern Somali Basin and to intersect the African margin near $7^{\circ} \mathrm{N}$ (Figure 12). The intersection of the gravity high with the African continental margin is marked by a broadening out of the continental margin and in particular a bathymetric high is observed in the lower continental slope which reaches to within $1500 \mathrm{~m}$ of the sea surface (Figure 12) (See profile WI921(c) in Figure 2). The geometry of the various tectonic elements (Figure 8) suggests that the ARS fracture zone traces the boundary between oceanic crust to the east and extended continental crust to the west. The $4^{\circ} \mathrm{N}$ bathymetric high can then be interpreted as representing the boundary between African continental crust 


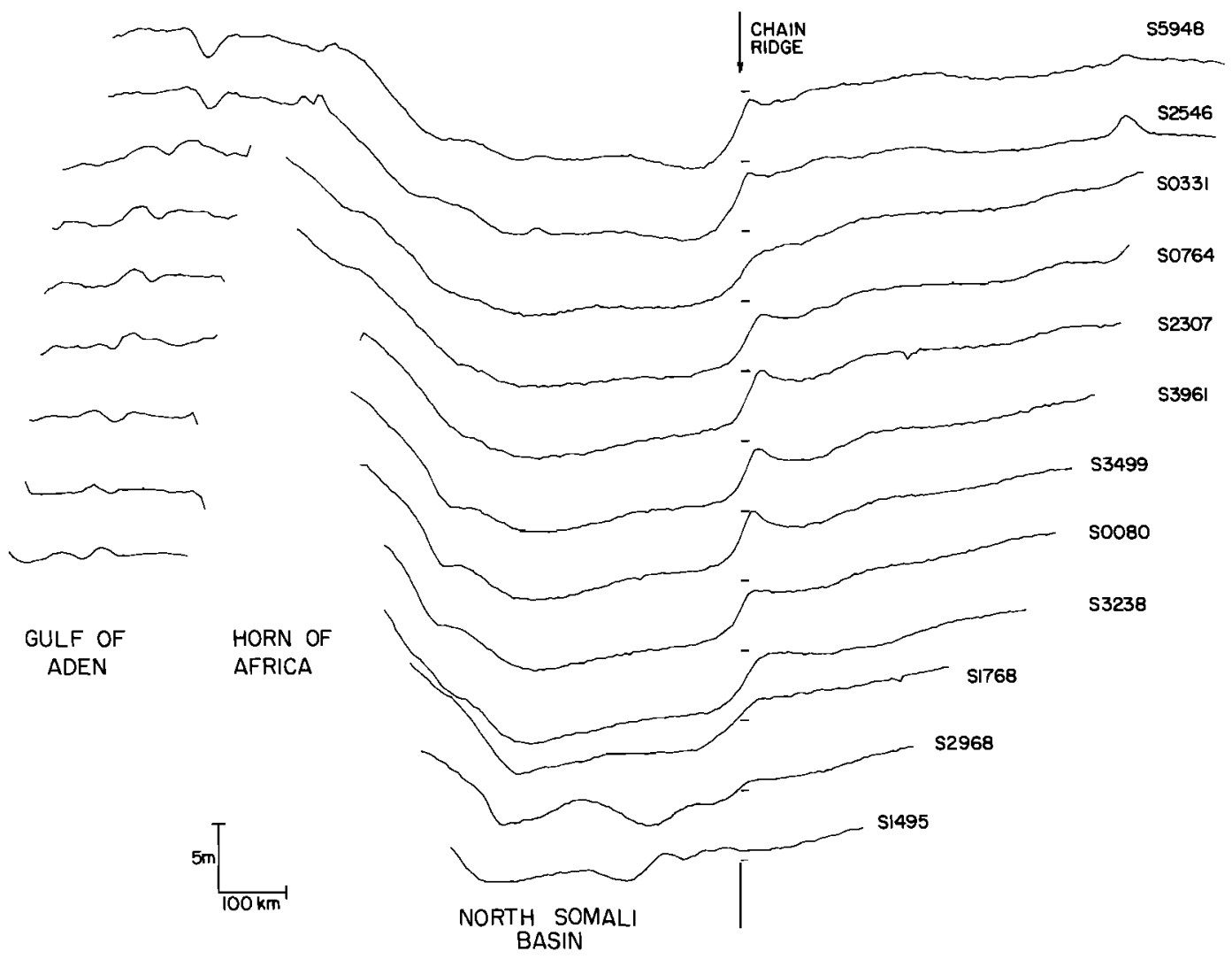

Fig 4b. SEASAT geoid profiles across the Northem Somali Basin. Track location is shown in Figure 4a. All profiles have been projected along $N 120^{\circ} \mathrm{E}$, perpendicular to Chain Ridge and the African continental margin. Short reference lines are spaced $5 \mathrm{~m}$ apart.

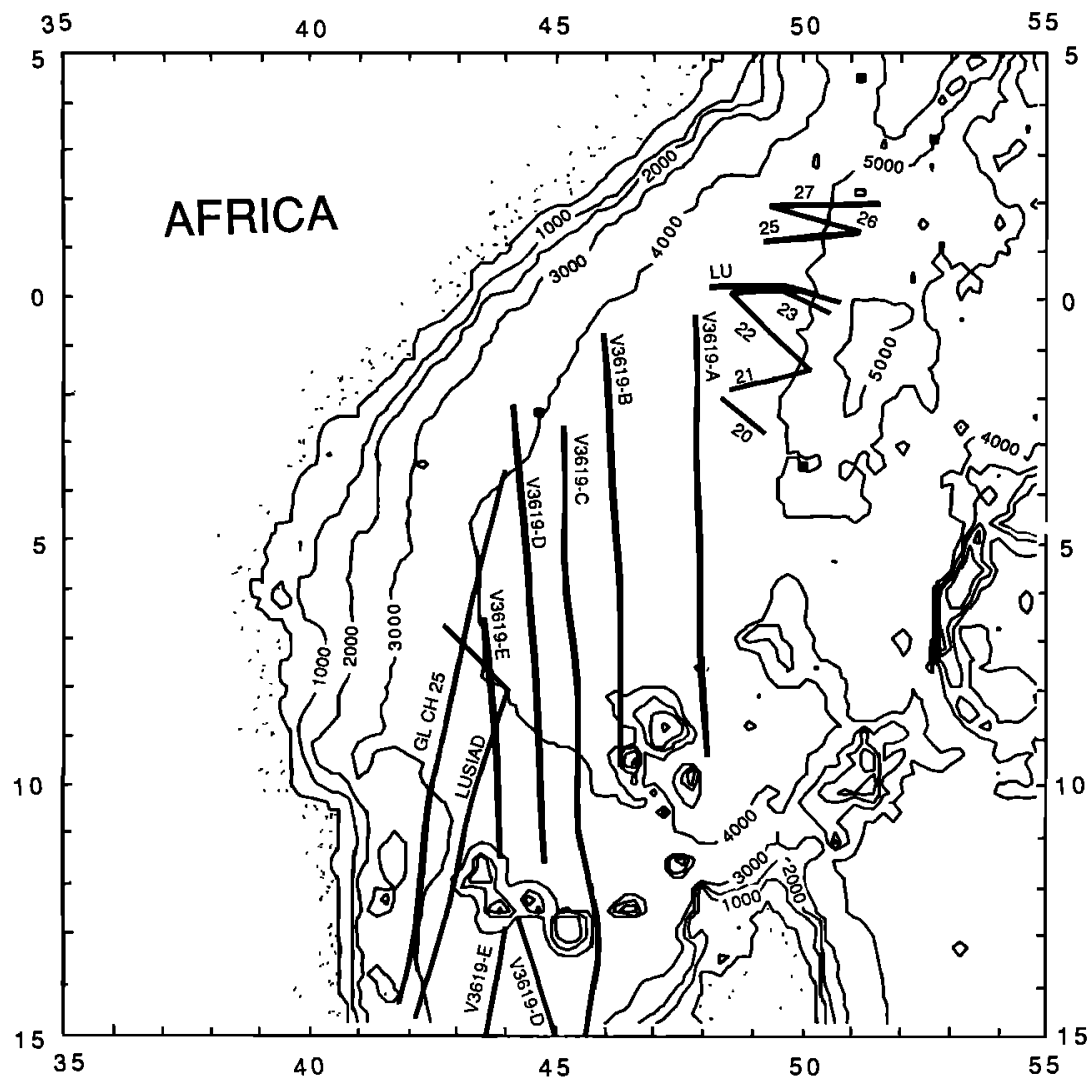

Fig 5a. Location of ship tracks for profiles in the Western Somali Basin (Figures, 5b, 6, 7 and 9). Track identification corresponds to these on profiles. Solid squares show DSDP sites. 


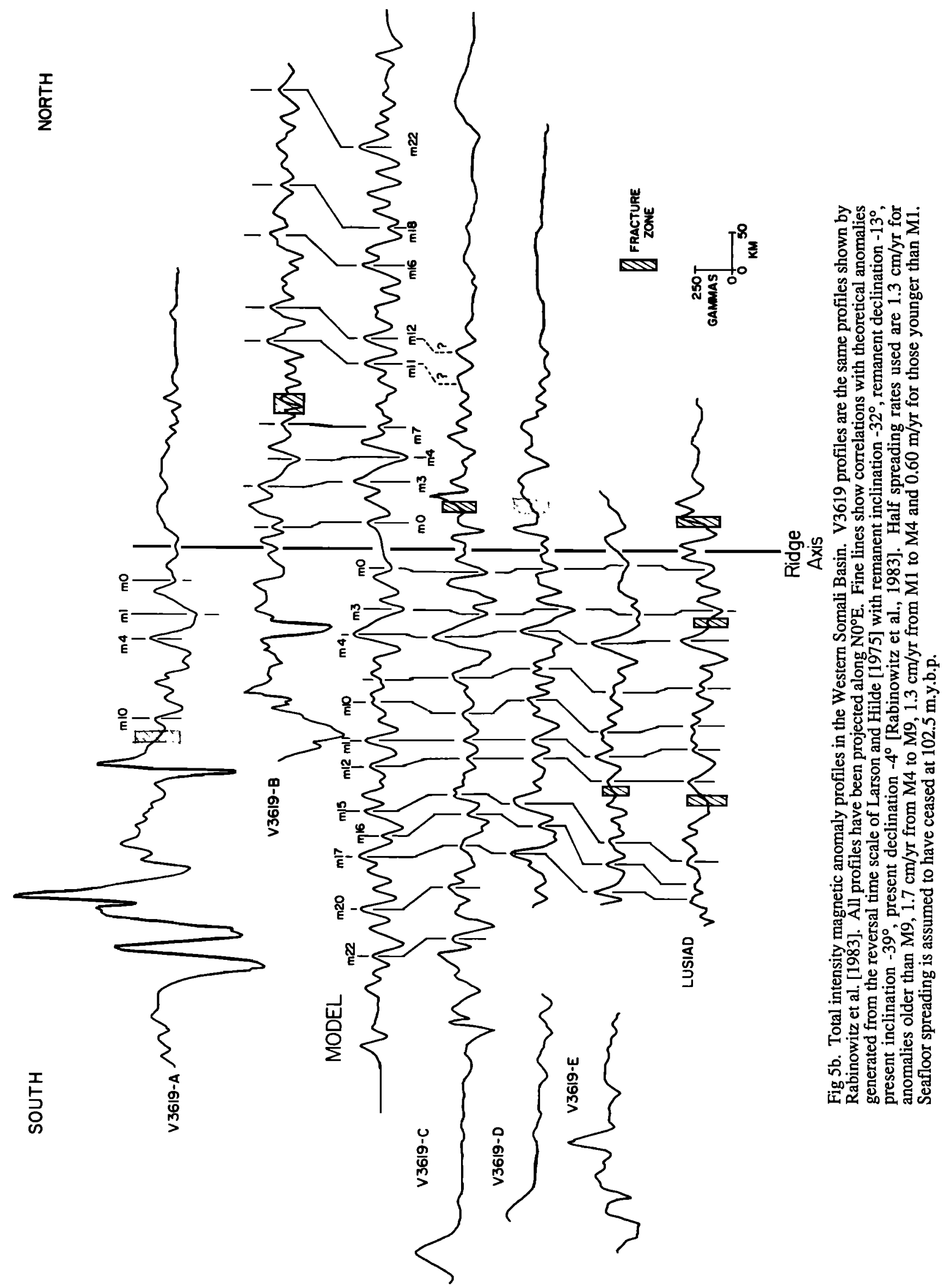




\section{WESTERN SOMALIBASIN MAGNETIC ANOMALIES}

SOUTH

NORTH

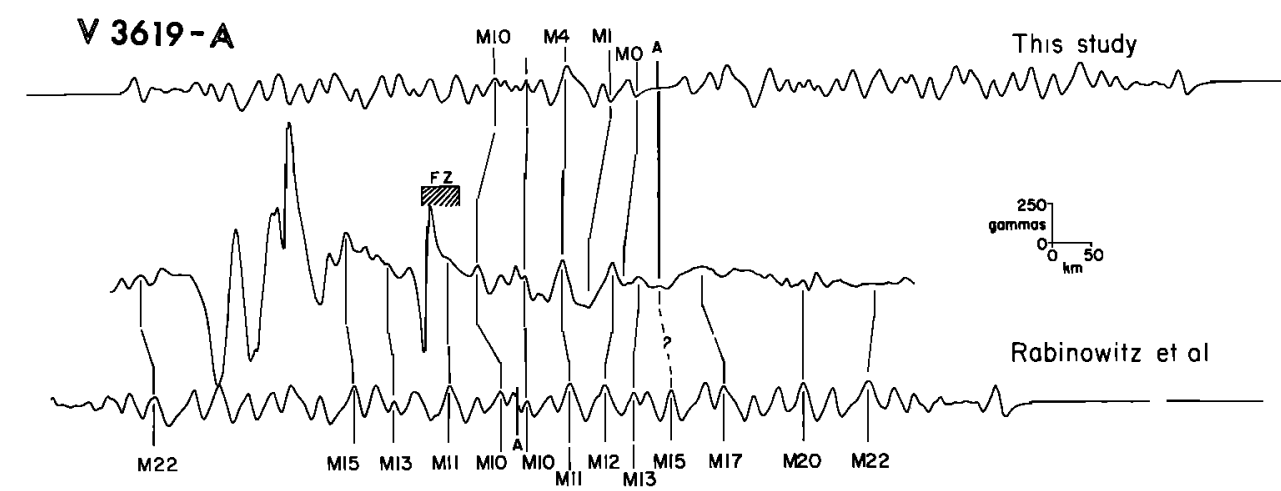

$$
\text { V } 3619-B
$$

This study

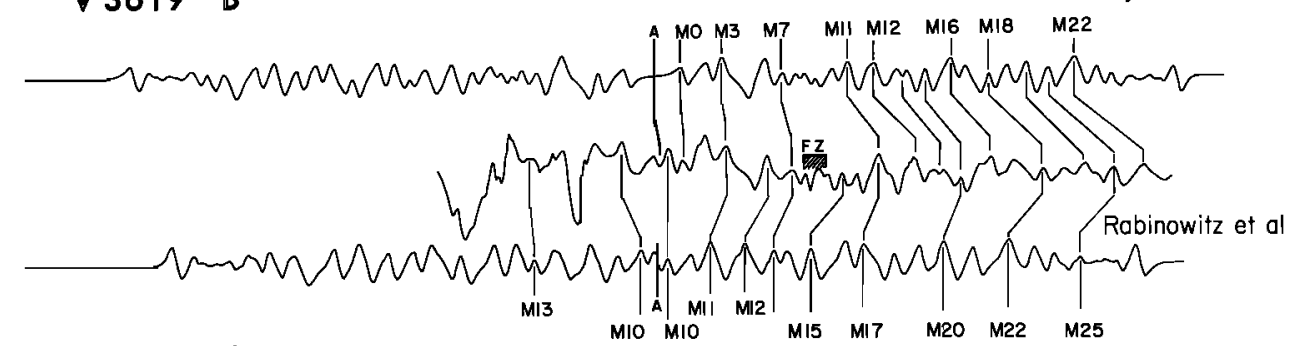

V 3619-C

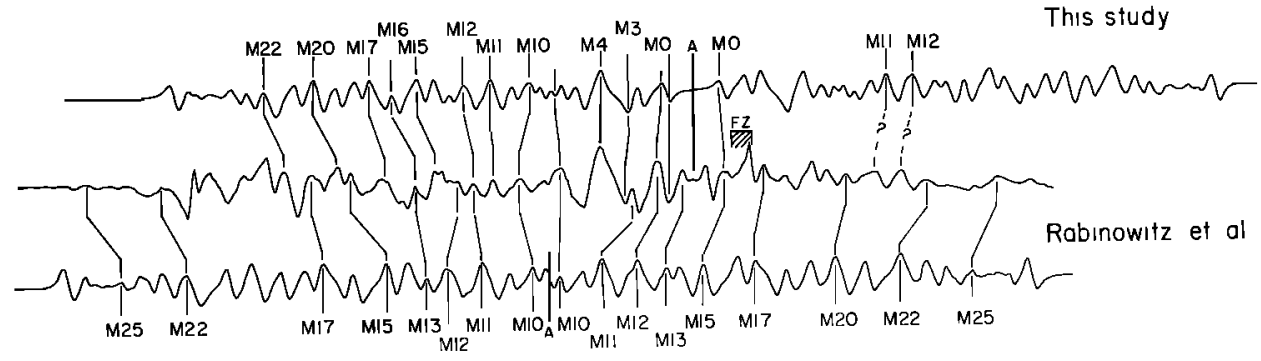

V $3619-D$

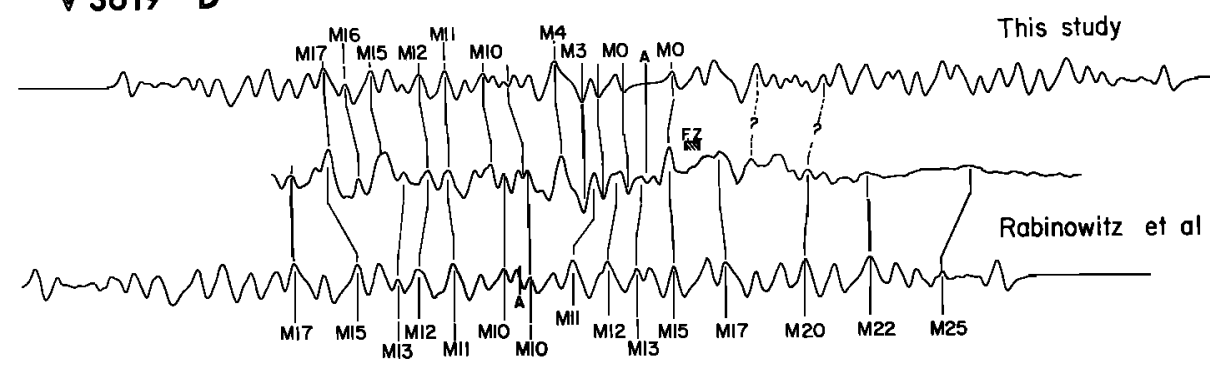

$$
\text { V 3619-E }
$$

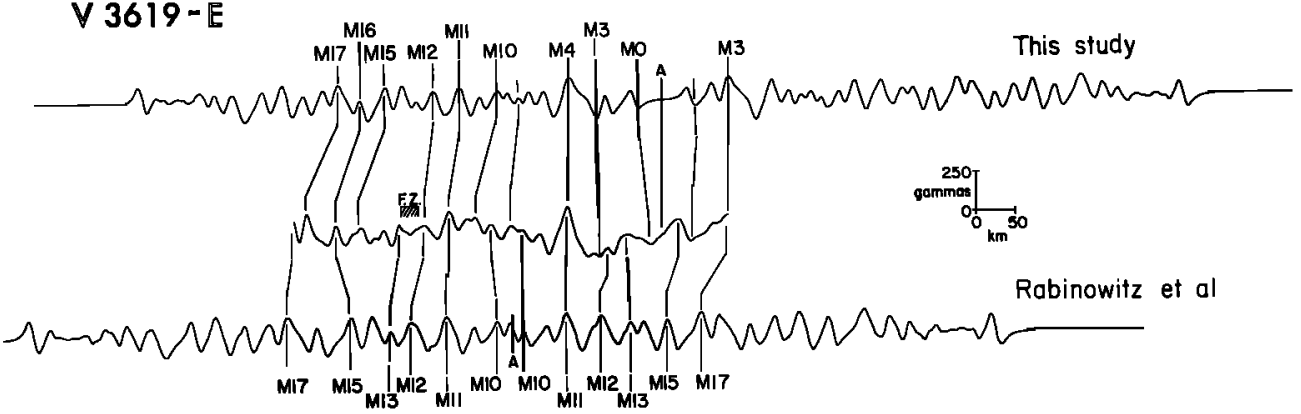

Fig 6. Bathymetry and free-air gravity profiles from the Western Somali Basin. All profiles are projected along $\mathrm{N}^{\circ} \mathrm{E}$. North is on the right. Note presence of small gravity low at location of relic ridge axis as determined from magnetic anomalies (Figure 5). Reference line at each end of bathymetry profiles is at depth of $4,000 \mathrm{~m}$. Location of profiles is given in Figure $5 \mathrm{a}$. 


\section{WESTERN SOMALI BASIN MAGNETIC ANOMALIES}

SOUTH

NORTH

\section{LUSIAD}

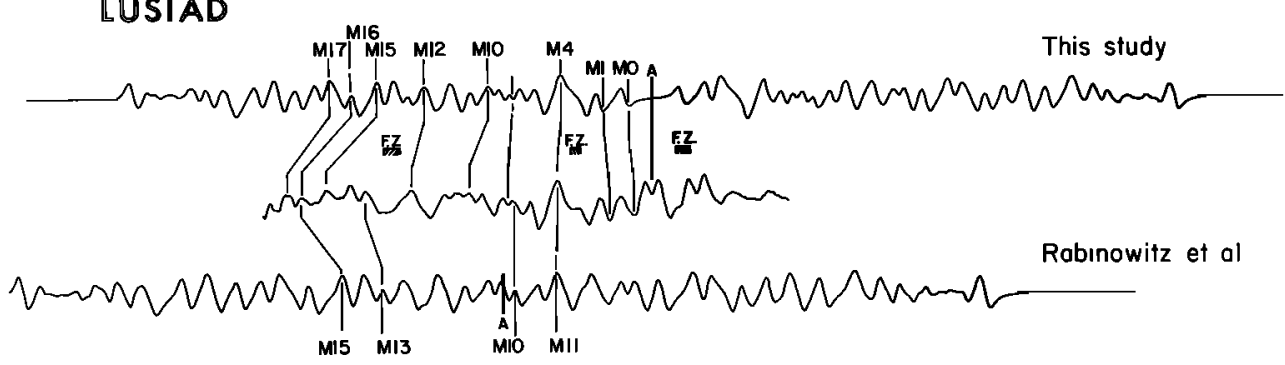

GLOMAR ChALLENGER

This study

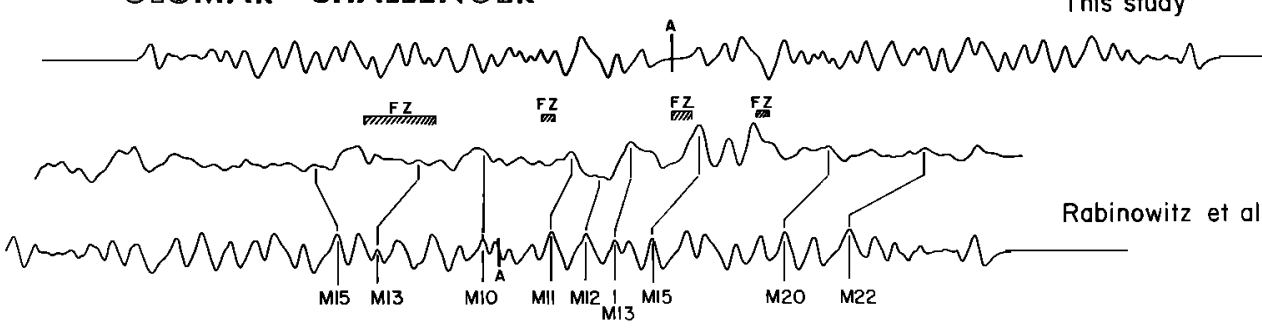

Fig. 6. (continued)

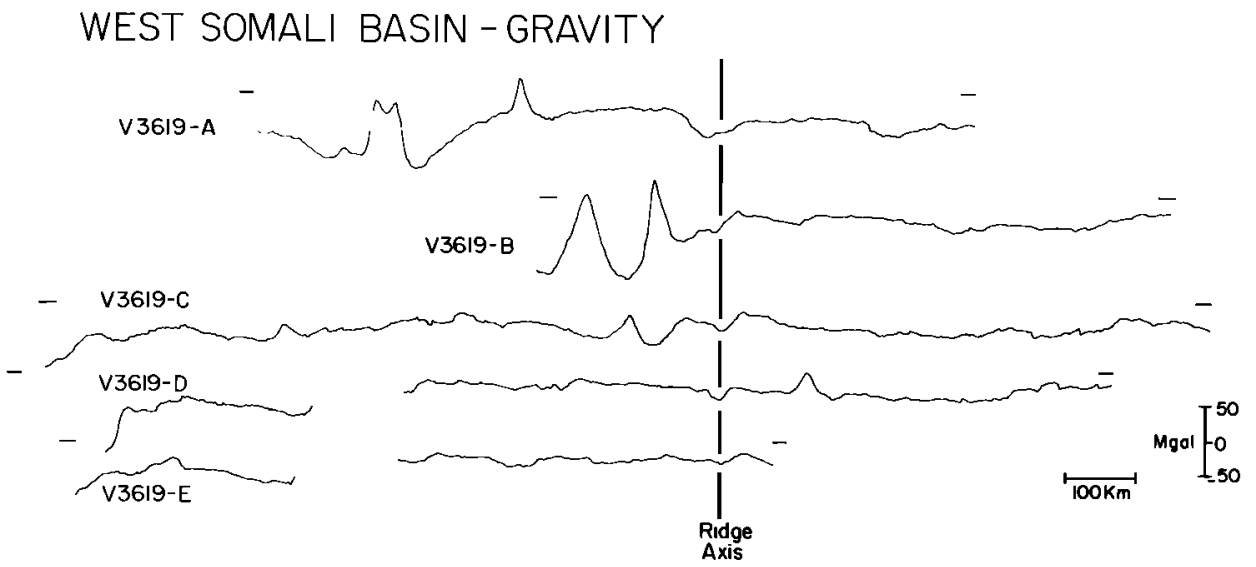

WEST SOMALI BASIN-BATHYMETRY

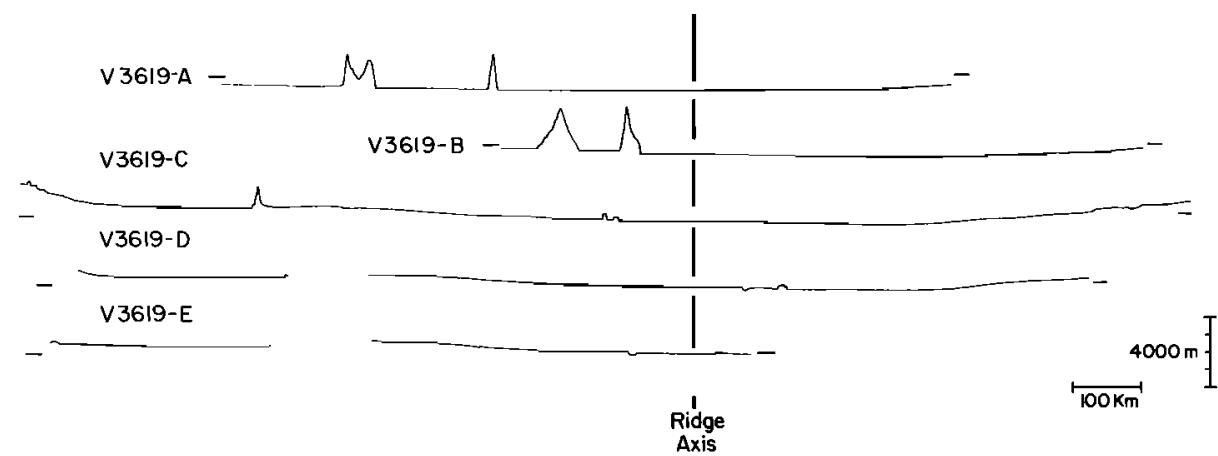

Fig 7. Comparison of correlations between magnetic anomaly data and seafloor spreading models by Rabinowitz et al. [1983] and those proposed in this study. For each profile, the observed data is shown in the center with the correlations proposed here above it and those of Rabinowitz et al. [1983] below. All models used the Larson and Hilde [1975] time scale and the same magnetic parameters as in Figure 5b. The Rabinowitz et al. [1983] model assumes a spreading rate of $1.7 \mathrm{~cm} / \mathrm{yr}$ and that spreading ceased at 121.1 m.y.b.p. 


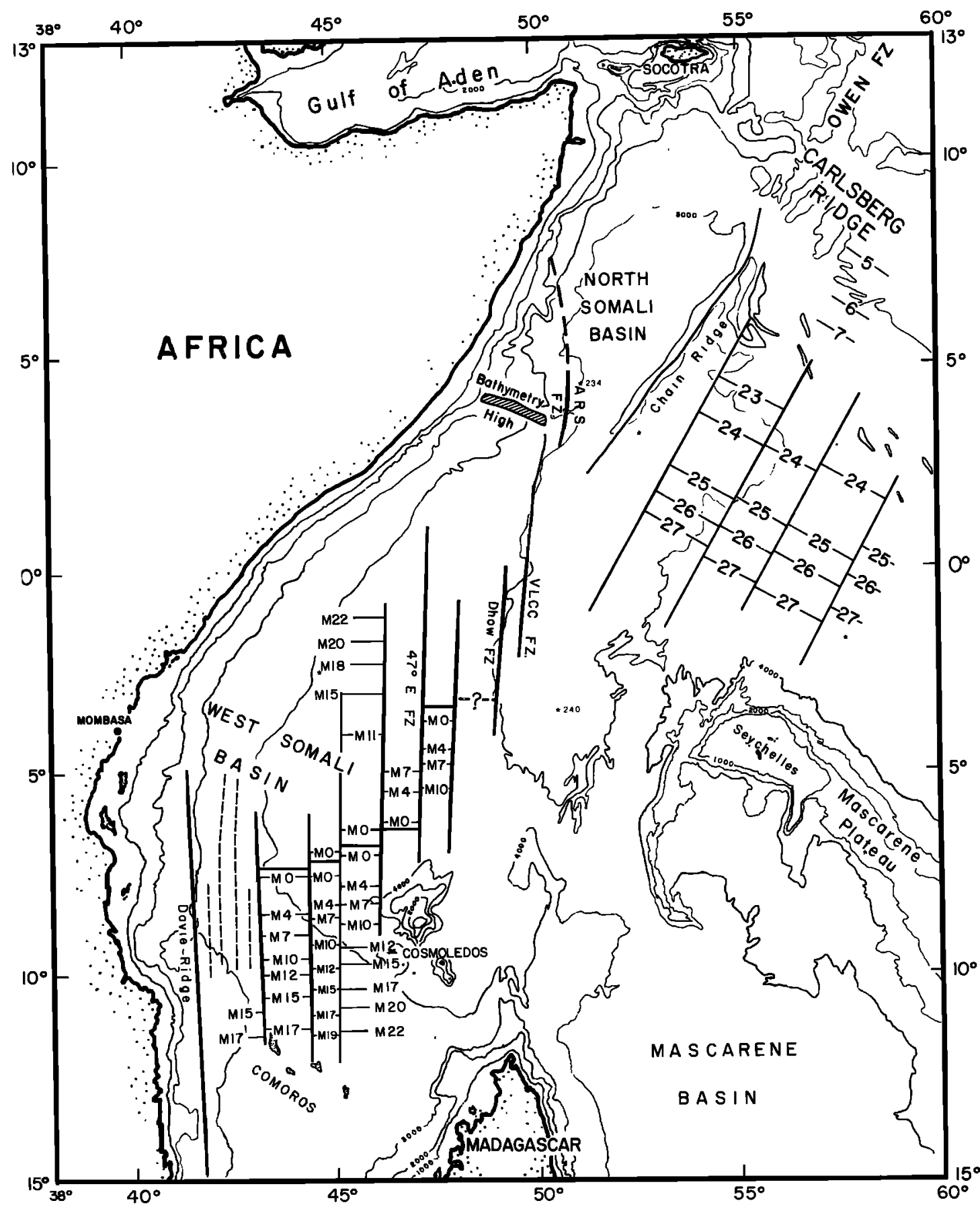

Fig 8. Summary chart showing location of fracture zones and seafloor spreading magnetic anomalies in the western Indian Ocean. Magnetic anomalies in western Somali Basin are based on correlations in Figure 5. Dashed lines just east of Davie Ridge are basement ridges mapped by Coffin and Rabinowitz [1987]. Fracture zones and anomalies on Carlsberg Ridge flank after Schlich [1982]. Small stars show locations of DSDP drill sites.

and oceanic crust created at the Western Somali Basin spreading center.

There are magnetic anomalies in the Northern Somali Basin east of the ARS fracture zone (Figure 14), although they are of a somewhat lower amplitude than those found in the Western Somali Basin (100-150 gammas compared to 250 gammas.). The Northern Somali Basin magnetic anomalies appear to be lineated in a nearly east-west direction, but it has not been possible to convincingly correlate them with the geomagnetic time scale.

The evidence presented above suggests that the Northern Somali Basin was created in the Late Jurassic and Early Cretaceous by the southward movement of East Gondwanaland. It thus serves as the third of a series of basins created at east-west trending spreading centers, the other two being the Mozambique and Western Somali Basins, separated 

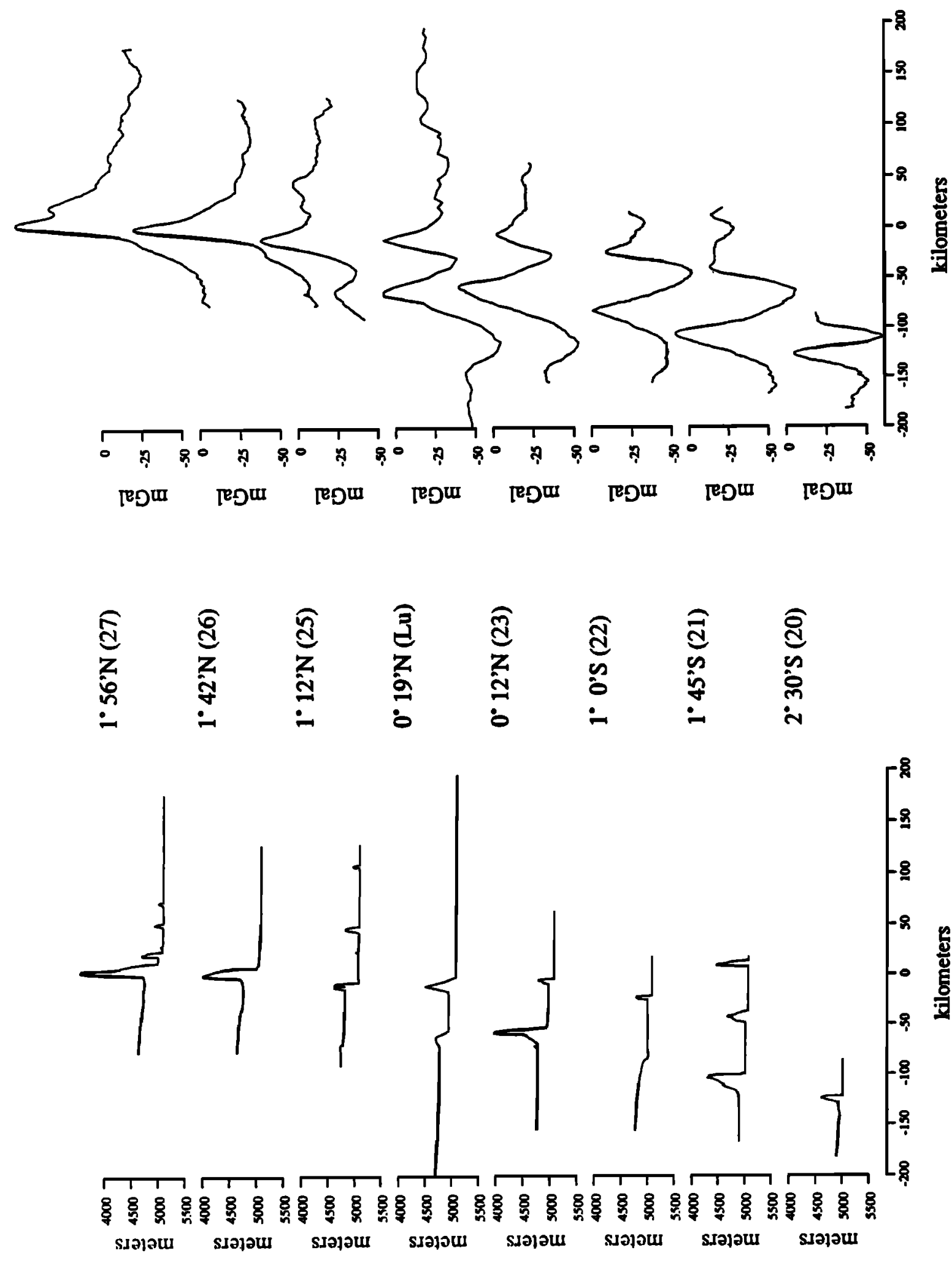


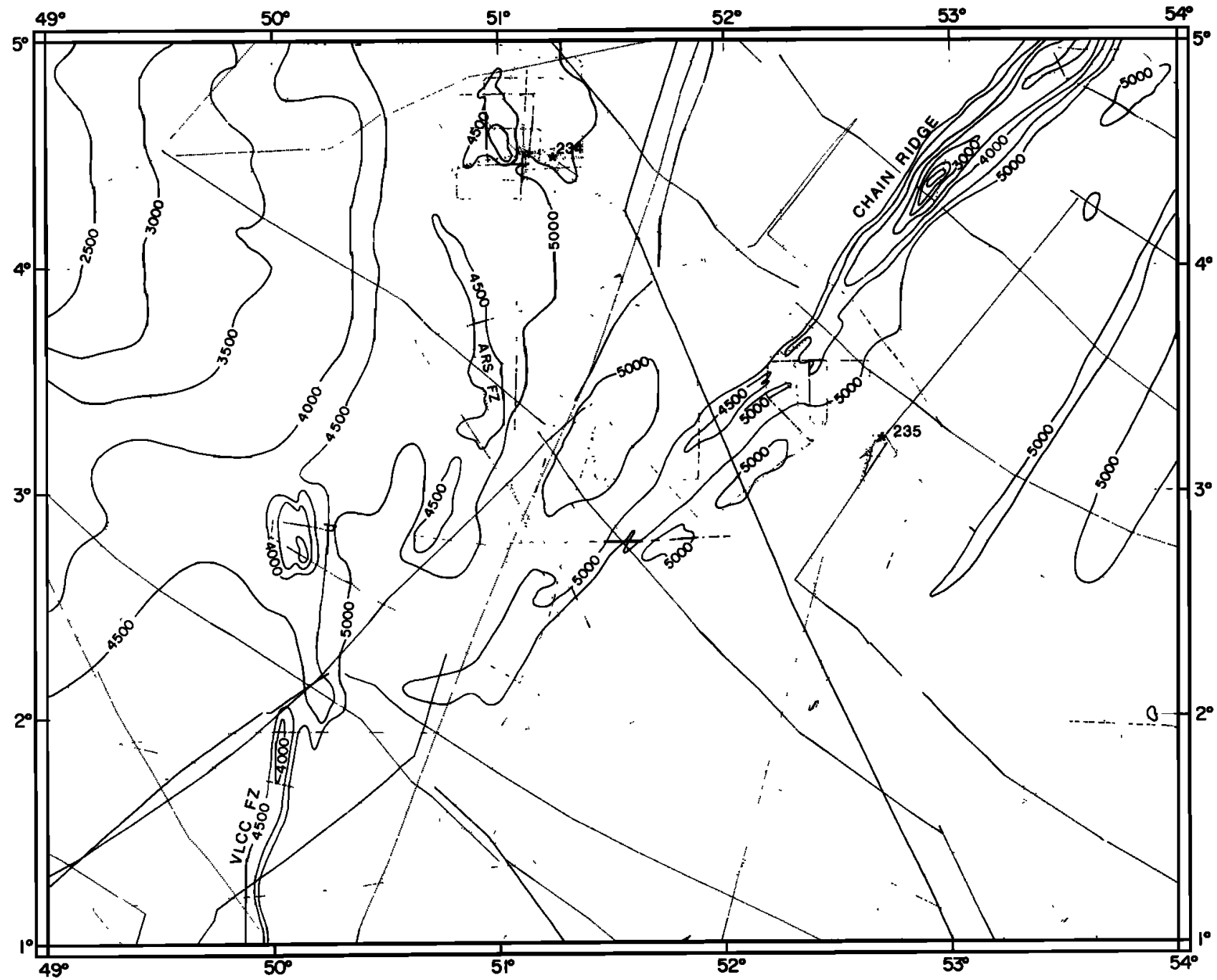

Fig 10. Bathymetric map, contoured at $500 \mathrm{~m}$ intervals of the southern end of Chain Ridge and the northern end of the VLCC fracture zone. Control is shown by dots at data points. Stars show location of DSDP drill sites.

by the Davie Ridge, an extremely long north-south trending fracture zone. The Dhow-VLCC-ARS complex appears to be a similar long fracture zone separating the Western Somai Basin and Northern Somali Basin spreading centers.

The original Northern Somali Basin was, however, rent asunder by the northward movement of India beginning in the mid- to Late Cretaceous [McKenzie and Sclater, 1971, Norton and Sclater, 1979]. Chain Ridge thus represents a boundary between the Late Jurassic-Early Cretaceous lithosphere of the Northern Somali Basin to the west created during the southward motion of India and the Late Cretaceous-Tertiary lithosphere to the east which was created at the Carlsberg Ridge during the northward motion of India. Well-developed Paleocene magnetic anomalies 23-27 have been mapped east of the Chain Ridge (Figure 8) [McKenzie and Sclater, 1971; Schlich, 1982].

Bosellini [1986] noted a distinct division in the East African continental margin at $6^{\circ} \mathrm{N}-7^{\circ} \mathrm{N}$ across a tectonic feature which he called the El Hamurre Escarpment. South of this feature, the margin was broken up by normal faulting in the Middle Jurassic and under-went significant subsidence in the Callovian while the area to the north was not affected by this faulting and was a region of shallow water or subaerially exposed during Jurassic and Early Cretaceous time [Bosellini, 1986].

The difference in the tectonics of the African margin was attributed by Bosellini [1986] to the southern section being a rifted continental margin formed by the motion of Madagascar away from Africa, while the northern section is a sheared continental margin. This suggestion is consistent with the observations presented here since the change in the nature of the margin occurs at the intersection of the ARS fracture zone with the margin and rifting of the Somalian margin north of $7^{\circ} \mathrm{N}$ would be largely transverse.

However, Bosellini [1986] argued that the northern portion of the margin was not formed by the southward motion of India but rather that India remained in place against Africa during the Jurassic and Early Cretaceous and that the Northern Somali Basin was created by the northward motion of India beginning in the Late Cretaceous. The main evidence cited for this suggestion is Late Cretaceous to early Cenozoic tectonic activity in unpublished well data from Northern Somalia.

However, the difference in basement depth and sediment thickness across Chain Ridge makes it unlikely that the 


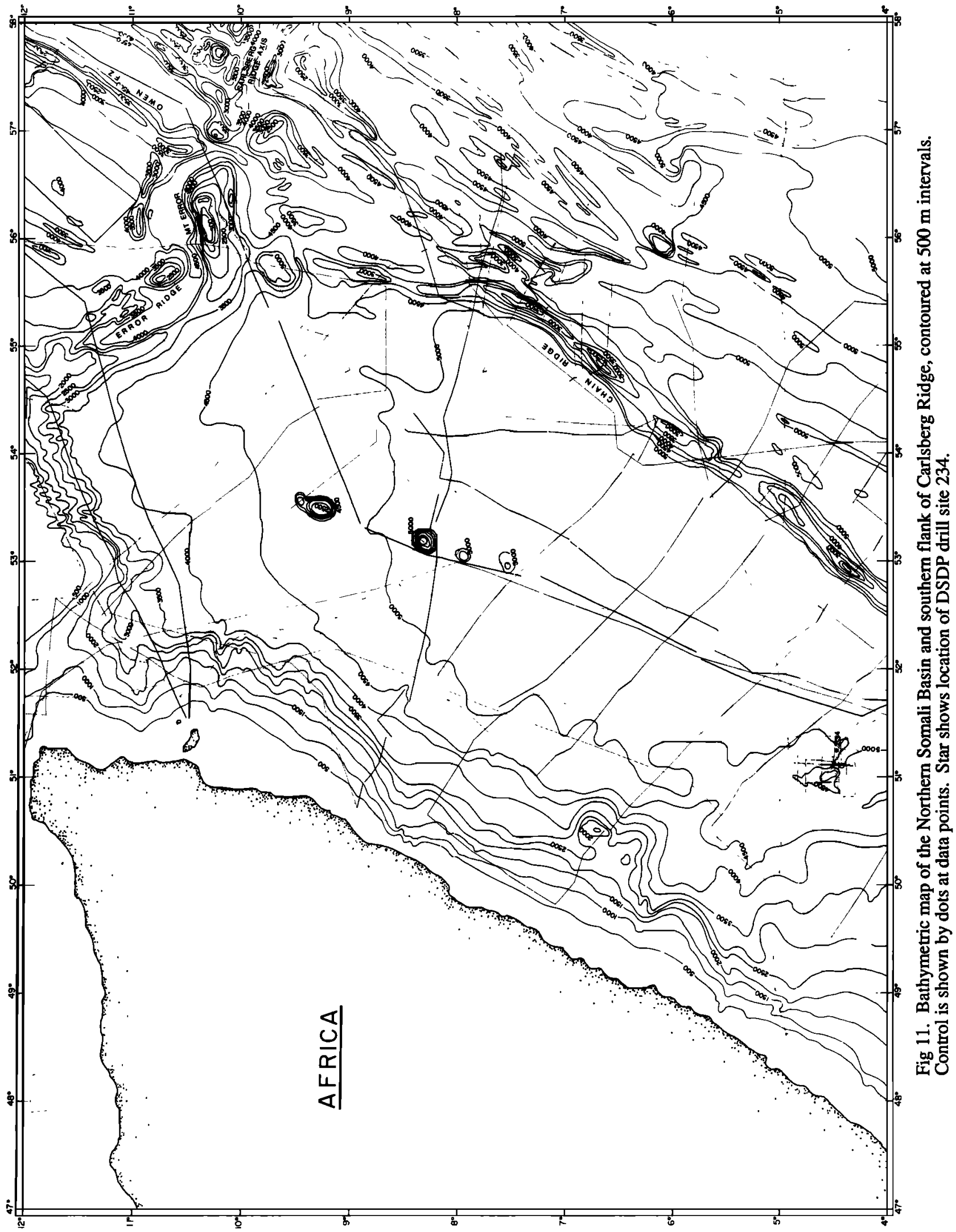




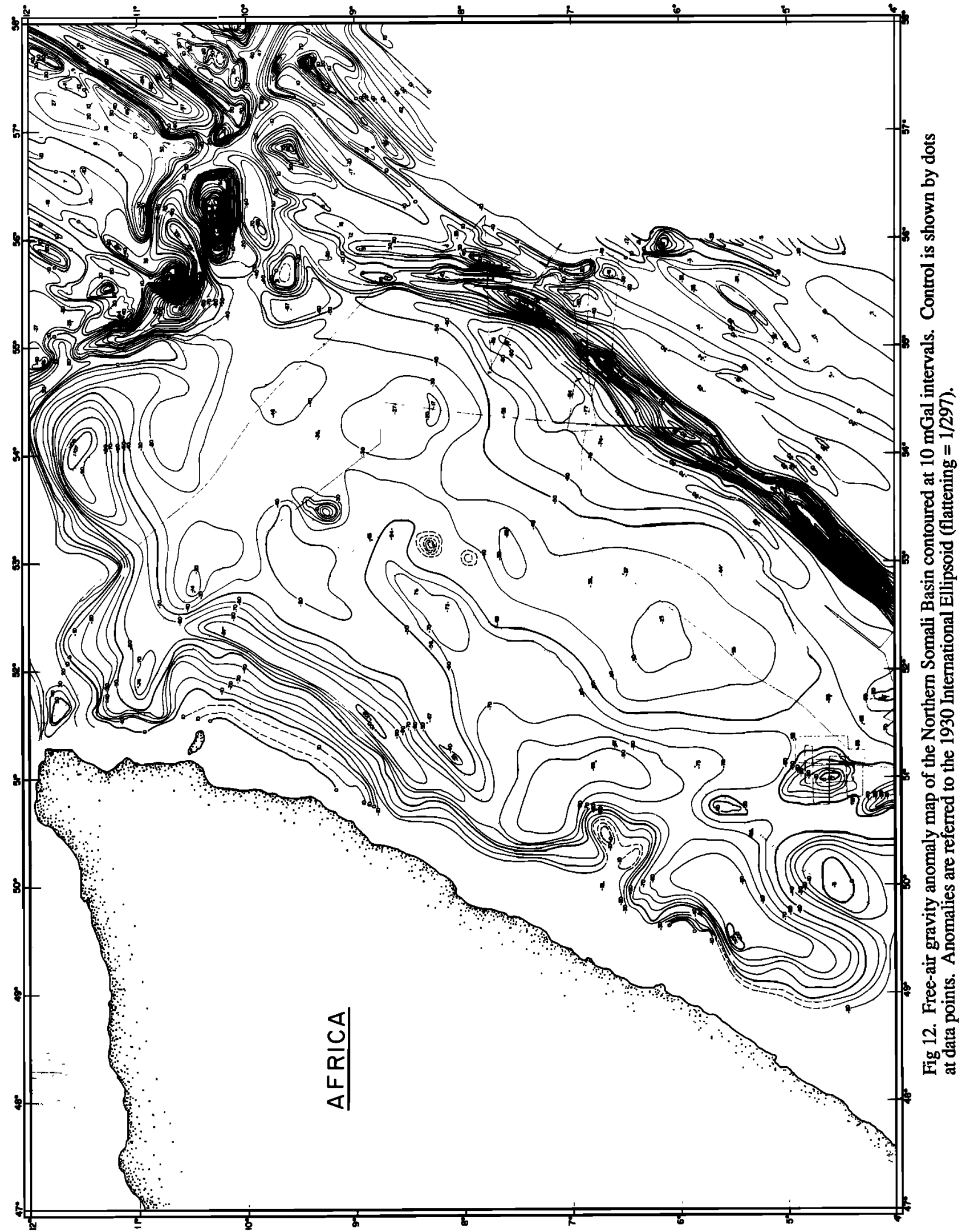


N FREE AIR GRAVITY
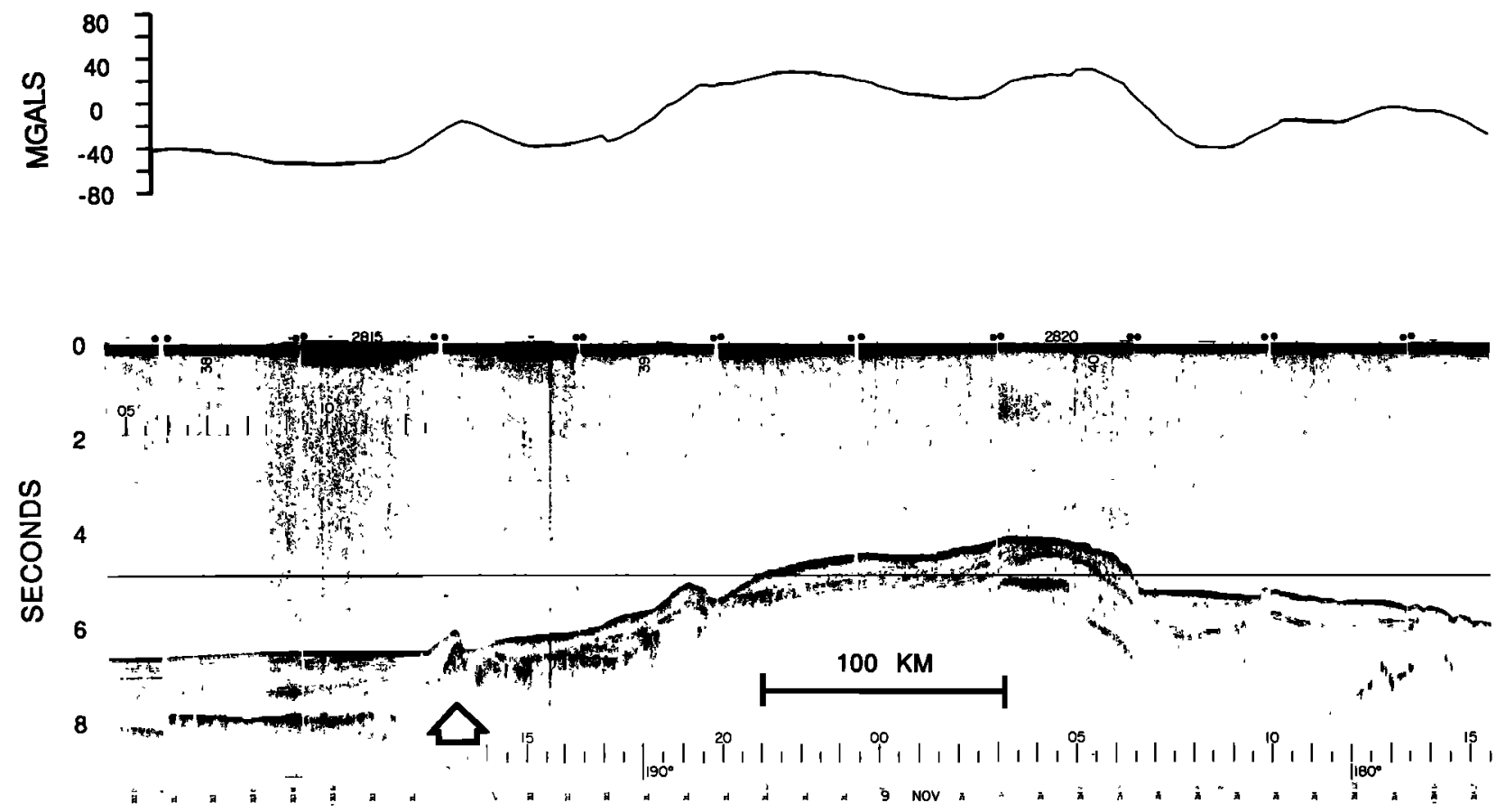

Fig 13. Single channel seismic reflection and free-air gravity anomaly profile across boundary between Northern and Western Somali Basin. Arrow marks location of basement peak and gravity high associated with northern continuation of the ARS fracture zone. Basement feature at far southern end of profile is the Dhow fracture zone. Location of profile is shown on Figure 2a.

Northern Somali Basin is of a similar age to the demonstrably Late Cretaceous-early Tertiary crust to the east. The Carlsberg Ridge flank to the east of Chain Ridge is characterized by maximum water depths of slightly more than $5000 \mathrm{~m}$, numerous exposed basement peaks and thin sediments (less than $0.5 \mathrm{~s}$.) (Figures 2 and 11). The Northern Somali Basin also has water depths of about $5100 \mathrm{~m}$, but the basin is underlain by at least $2 \mathrm{~s}$. ( $\sim 2 \mathrm{~km})$ of sediment (Figure 12). The sediment thickness and basement depths in the Northern Somali Basin are similar to those found in the Western Somali Basin [Coffin, 1985; Coffin et al., 1986]. The contrast drawn by Bunce et al. [1967] between the Northern and Southern Somali Basins is actually between the Northern Somali Basin and the region east of the Dhow-VLCC fracture zone complex.

\section{Gravity Field of the Northern Somali Basin}

A gravity map of the Northern Somali basin, contoured at $10-\mathrm{mGal}$ intervals, is presented in Figure 12. The Northern Somali Basin is surrounded by high amplitude anomalies and steep gravity gradients. Chain Ridge forms a continuous feature along the eastern boundary of the basin (Figures 11 and 12). South of $7^{\circ} 40^{\prime} \mathrm{N}$, it has a NE-SW trend and generally reaches to within $2500-3500 \mathrm{~m}$ of the sea surface (Figures 2 and 11) with peaks shallower than $2000 \mathrm{~m}$ found at $5^{\circ} 20^{\prime} \mathrm{N}$ and $6^{\circ} 40^{\prime} \mathrm{N}$. The gravity anomalies associated with this section of Chain Ridge consist of a sharp gravity high over the topographic ridge and a broader low to the northwest on the Northern Somali Basin side of Chain Ridge (Figure 12). The gravity high over Chain Ridge is generally in the range of +60 to $+80 \mathrm{mGal}$ while the low to the west is about
-70 to $-80 \mathrm{mGal}$. The level of the regional gravity field east of Chain Ridge is about -10 to $-20 \mathrm{mGal}$.

Chain Ridge changes trend at $8^{\circ} \mathrm{N}$ and continues almost due north toward the southwestern corner of Mount Error, the large seamount located at $10^{\circ} \mathrm{N}$ between $55^{\circ} 40^{\prime} \mathrm{E}$ and $56^{\circ} 40^{\prime} \mathrm{E}$ (Figure 11). The topographic expression of the ridge is only slightly less than that of the southern section although the gravity anomalies over it are considerably reduced with a peak to peak amplitude of about $65 \mathrm{mGal}$ rather than $140 \mathrm{mGal}$ (Figure 12).

The northwestern end of the Carlsberg Ridge rift valley is clearly evident on both the bathymetric map (Figure 11) and free-air gravity map (Figure 12) between $57^{\circ} \mathrm{E}$ and $58^{\circ} \mathrm{E}$ as is the Owen fracture zone extending to the northeast from the termination of the Carlsberg Ridge. The northeastern boundary of the Northern Somali Basin is marked by Error Ridge, which extends from the Socotra continental margin to Mount Error (Figure 11). Southeast of $55^{\circ} \mathrm{E}$ Error Ridge is a double peaked feature characterized by an extremely large negative (<-150 mGal) gravity anomaly located between the two peaks. A northeast trending ridge flank fabric can be observed north of Error Ridge associated with seafloor spreading at the East Sheba Ridge and southeast of Chain Ridge associated with spreading at the Carlsberg Ridge. The northern and western boundaries of the Northern Somali Basin are marked by bands of negative gravity anomalies on the lower continental slope which reach values of the order of $-100 \mathrm{mGal}$. Where data are available on the continental shelf, there appears to be a small gravity high present, so that the negative anomalies on the lower continental slope comprise the negative half of a continental margin edge effect anomaly. 
NORTH SOMALI BASIN
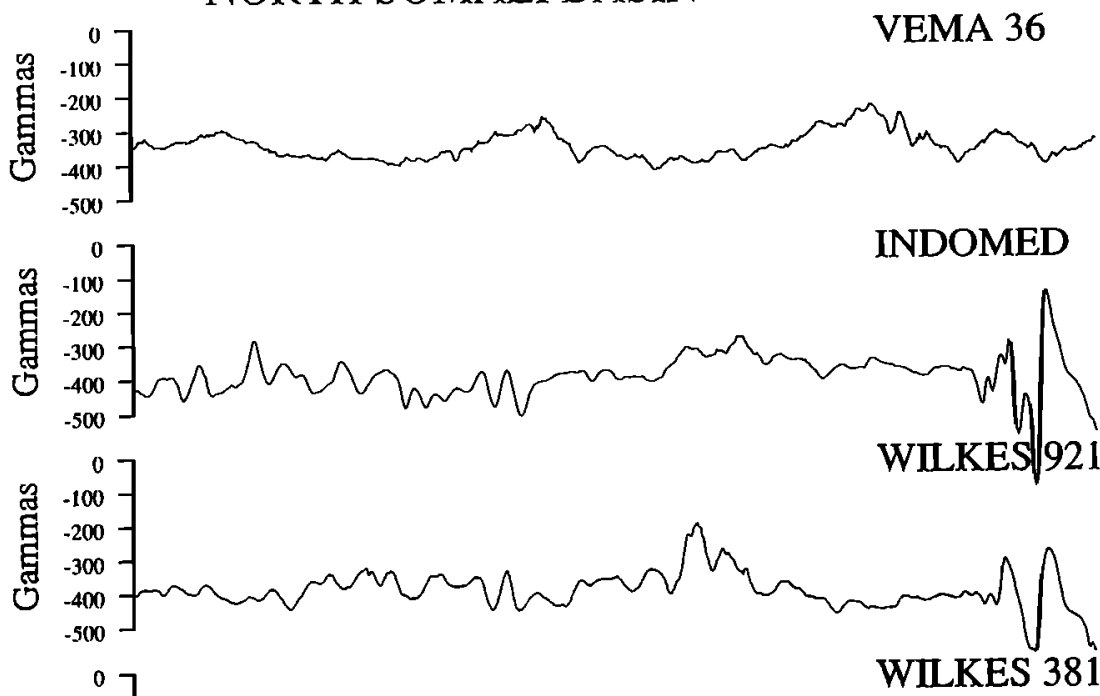

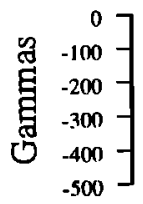

WILKES 381

$\left.\begin{array}{rr} & 0 \\ \dddot{G} & -100 \\ \text { : } & -200 \\ \hdashline & -300 \\ \hdashline & -400 \\ \hdashline & -500\end{array}\right]$

VEMA 35

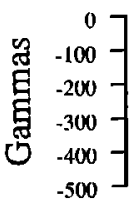

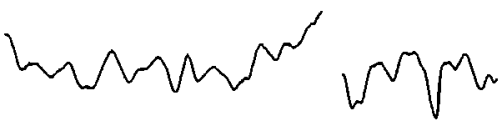

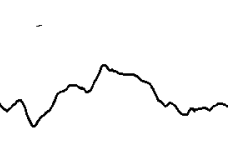

WILKES 916

\begin{tabular}{|c|c|c|c|c|c|c|c|c|c|c|}
\hline $\begin{array}{c}-500 \\
\end{array}$ & $\begin{array}{c}1 \\
-400\end{array}$ & $\begin{array}{c}1 \\
-300\end{array}$ & $\begin{array}{c}1 \\
-200\end{array}$ & -100 & 0 & 100 & 200 & 300 & 400 & 500 \\
\hline
\end{tabular}

Fig 14. Total intensity magnetic anomaly profiles from the Northern Somali Basin. Profiles are projected along $\mathrm{N} 0^{\circ} \mathrm{E}$ and north is to the right. The $0 \mathrm{~km}$ reference on the horizontal scale is at $7^{\circ} \mathrm{N}$. Location of profiles is shown in Figure 2a.

TABLE 1. Values of Model Parameters

\begin{tabular}{ll}
\hline \multicolumn{1}{c}{ Parameter } & \multicolumn{1}{c}{ Value } \\
\hline & \\
\hline & $125 \mathrm{~km}$ \\
Lithospheric thickness & $31.2 \mathrm{~km}$ \\
Continental crustal thickness & $5 \mathrm{~km}$ \\
Oceanic crustal thickness & $2.8 \mathrm{~g} \mathrm{~cm}^{-3}$ \\
Crustal density $\left(0^{\circ} \mathrm{C}\right)$ & $3.33 \mathrm{~g} \mathrm{~cm}^{-3}$ \\
Mantle density $\left(0^{\circ} \mathrm{C}\right)$ & $1.03 \mathrm{~g} \mathrm{~cm}^{-3}$ \\
Water density & $3.4 \times 10^{-5}{ }^{\circ} \mathrm{C}^{-1}$ \\
Coefficient of thermal expansion & $1333{ }^{\circ} \mathrm{C}$ \\
Asthenospheric temperature & $0.0075 \mathrm{cal}^{-(\mathrm{deg} \mathrm{cm} \mathrm{s})}{ }^{-1}$ \\
Thermal conductivity & $0.008 \mathrm{~cm} 2 \mathrm{~s}^{-1}$ \\
Thermal diffusivity &
\end{tabular}

The regional level of the free-air gravity anomalies in the center of the Northern Somali Basin is -25 to $-40 \mathrm{mGal}$, which is considerably less than the values of 0 to $+10 \mathrm{mGal}$ found north of Error Ridge or -10 to $-20 \mathrm{mGal}$ found east of Chain Ridge. However, the form of the free-air gravity anomalies over the Northern Somali Basin is not that of a concave bowlshaped depression. Rather, large negative anomalies are found completely around the margins of the basin with values generally increasing toward the center resulting in a convex upward form to the anomalies (Figure 12). This suggests that the negative gravity anomalies and geoid low associated with the Northern Somali Basin may result from the nature of its boundaries rather than some peculiarity associated with the basin as a whole.

Chain Ridge marks a lithospheric age discontinuity of about 80 m.y. The lithosphere to the northwest, within the Northern Somali Basin, is of Lower Cretaceous or Late Jurassic age, while the lithosphere to the southeast, on the southern flank of 


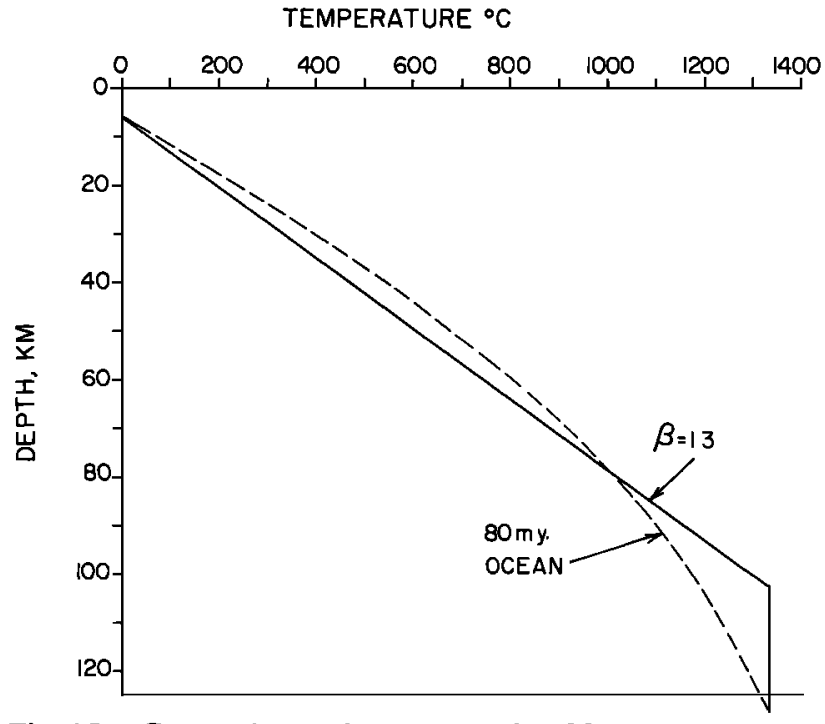

Fig 15. Comparison of geotherm for $80 \mathrm{~m} . y$. ocean assuming an asymptotic plate thickness of $125 \mathrm{~km}$ with geotherm used to approximate it as an initial condition for model calculations. The two geotherms results in initial depths that differ only by $20 \mathrm{~m}$ and nearly identiical subsidence curves with difference in depth decreasing with time. the Carlsberg Ridge, is early Tertiary or Late Cretaceous in age [Schlich, 1982] (See Figure 8). A number of investigators have pointed out that large offset fracture zones will be associated with distinctive gravity and geoid anomalies as a result of the contrast in lithospheric thermal structure across them. Louden and Forsyth [1976] showed that the gravity thermal edge effect should be small, especially when the effects of lateral heat conduction are considered. They concluded that the shallow crustal structure will dominate the gravity anomalies. However, Crough [1979] pointed out that the geoid is much more sensitive to the deeper density variations and showed that the geoid signal expected over a fracture zone is a step up from the older to the younger side. The theoretical initial geoid step across a fracture zone can be shown to be about $0.15 \mathrm{~m}$ per million years of offset [Haxby and Turcotte, 1978; Sandwell and Schubert, 1980]. If the lithosphere continues to cool indefinitely, this offset will be maintained since the geoid anomaly associated with the cooling half-space model of a mid-ocean ridge has been shown to be linear with age [Haxby and Turcotte, 1978]. However, if the lithosphere approaches some maximum thickness, as is suggested by studies of oceanic depths [Parsons and Sclater, 1977], then the geoid step across a fracture zone will decrease with time [Detrick, 1981].

A number of studies [Detrick, 1981; Sandwell and Schubert, 1982a; Cazenave et al., 1982, 1983] have attempted to determine the amplitude of the geoid step across large offset fracture zones and use the variation in the amplitude to determine the lithospheric thickness and thermal parameters.
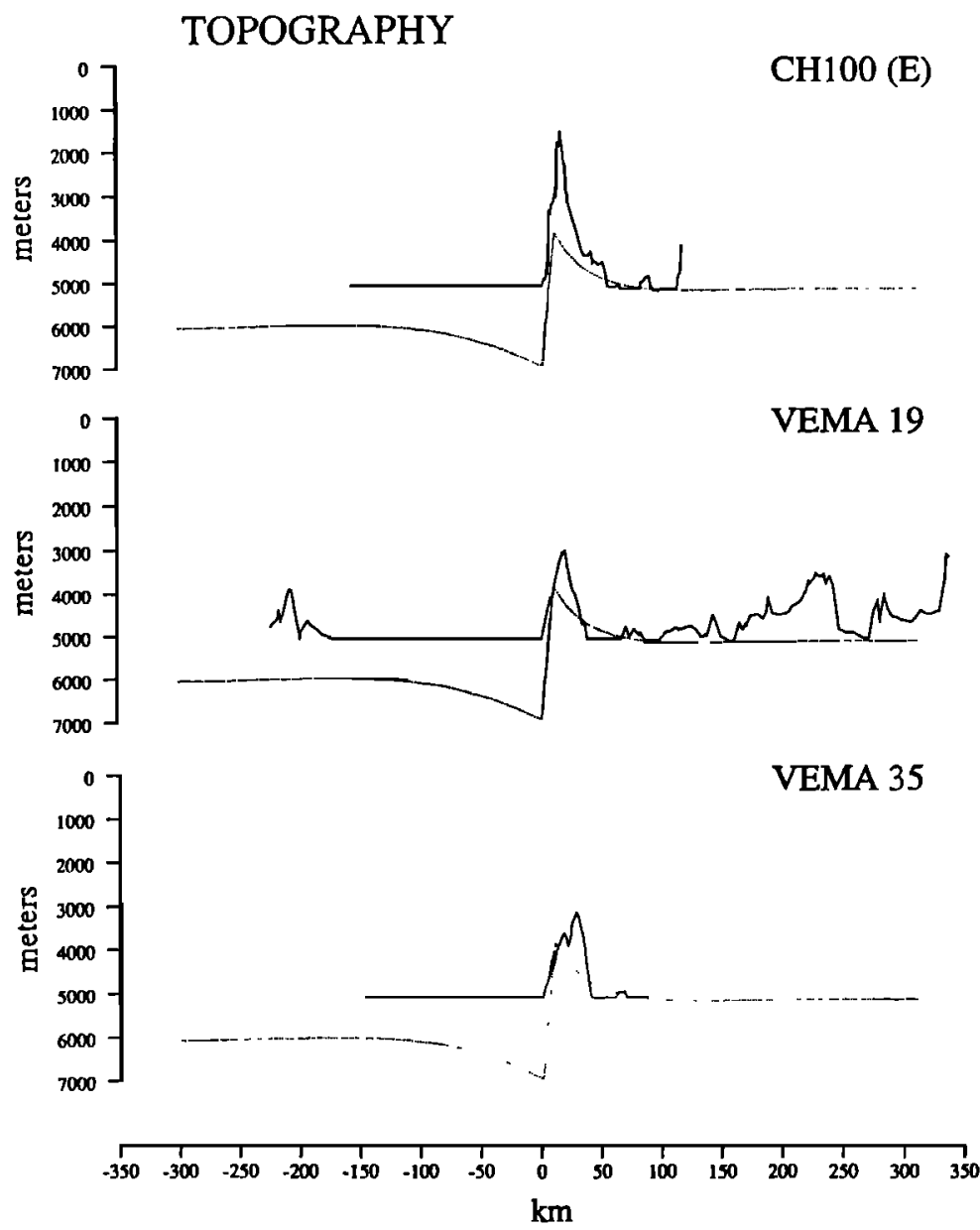

Fig 16. Upper surface of lithosphere resulting from calculation of differential subsidence across Chain Ridge (dotted curve), compared with three observed bathymetric profiles (solid curve). Note that calculated depths are assumed to be water loaded (no sediments). Location of observed profiles is shown in Figure $2 \mathrm{a}$. 


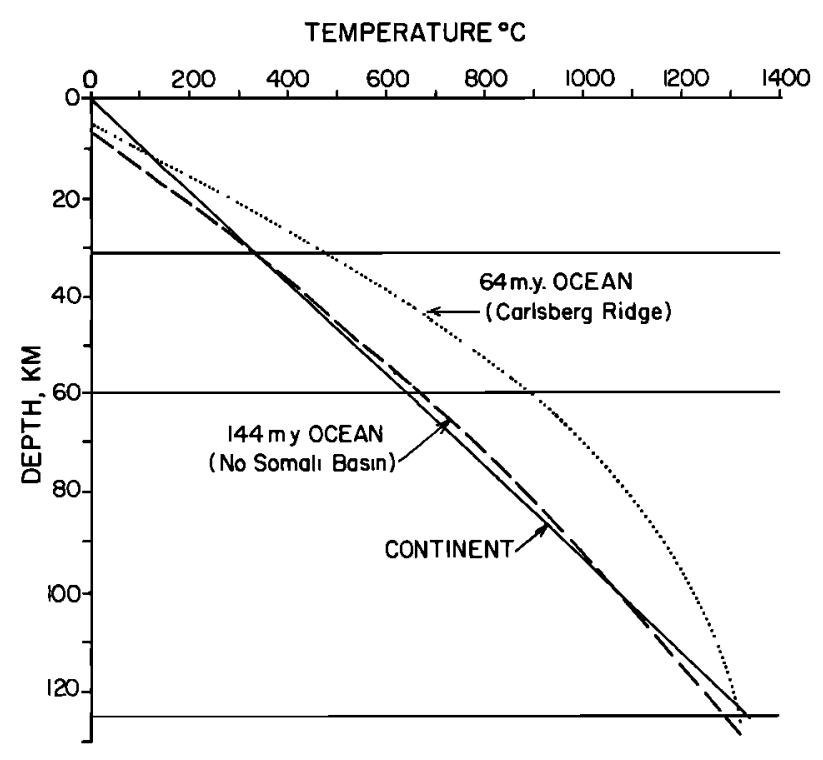

MANTLE
$333^{\prime} 330^{\prime}$
DENSITY $\mathrm{g} / \mathrm{cm}^{3}$

$$
\begin{aligned}
& \text { CRUST } \\
& 2.80
\end{aligned}
$$

Fig 17. Geotherms used to determine densities for gravity and geoid calculations. Oceanic geotherms were calculated assuming thermal parameters given in Table 1. Densities for model calculation were determined by calculated average temperature difference between oceanic and continental lithosphere in each of three depth ranges delineated by horizontal lines and converting temperature difference to density difference using coefficient of thermal expansion of $3.4 \times 10-5^{\circ} \mathrm{C}-1$.

The fracture zones most commonly used for these studies are the Mendocino fracture zone in the northeastern Pacific and the Udintsev and Eltanin fracture zones in the south-eastern Pacific. The reason that these fracture zones were chosen is that they trend reasonably normal to Seasat orbits and are characterized by large age offsets. The age difference across the Mendocino fracture zone is 25-30 m.y. [Detrick, 1981], while it is about $20 \mathrm{~m}$.y. across the Udintsev fracture zone and as much as 35 m.y. across the Eltanin Complex (combined Heezen and Tharp fracture zones) [Cazenave et al., 1983].

The crustal ages on either side of the Chain Ridge are considerably greater than those at locations where the fracture zone studies were carried out. However, the age contrast across Chain Ridge is about $80 \mathrm{~m} . y$. or more than twice that observed at the large Pacific fracture zones. Thus this effect must be considered in determining the origin of the Northern Somali Basin gravity and geoid low.

Another factor that must be considered in examining the gravity and geoid anomalies resulting from Northern Somali Basin boundary structures is the lithospheric flexure resulting from differential subsidence across Chain Ridge. Sandwell and Schubert [1982b] used bathymetric profiles across the large northeastern Pacific fracture zones to demonstrate that the basement offset across the fracture zones does not change with age and is equal to the initial offset at the ridge crest-transform intersection. This implies that the fossil fracture zone is "locked" and that significant vertical slip does not occur. The different thermal structure on either side of the fossil fracture zone will result in differential subsidence as the lithosphere cools and a characteristic flexure of the lithosphere will develop in the vicinity of the fracture zone. Sandwell and Schubert [1982b] showed that the resulting stresses, although large, are reasonable. The maintenance of the fracture zone scarp and the resulting flexure will clearly have a large effect on the gravity anomalies associated with the fracture zone, which are sensitive to the shallow crustal structure. Sandwell [1984] found that these factors will also have an important effect on the form of the geoid anomaly across the fracture zone. In particular, he found that flexural effects could explain the fact that the geoid step associated with fracture zones remains sharp into very old crust instead of becoming progressively shallower as the result of lateral heat conduction.

The contrast in thermal structure across Chain Ridge and the flexural response to differential subsidence were modeled using a technique developed by Steckler [1981] to determine the temperature structure of the cooling lithosphere which allows lateral variation in the initial thermal conditions and which also allows the initial bathymetric relief to be "frozen in" with differential subsidence treated as a flexural couple. The values assumed for thermal parameters and densities are given in Table 1 and are discussed by Steckler [1981] and Cochran [1982, 1983]. A lithospheric thickness of $125 \mathrm{~km}$ was assumed. The initial condition was a mid-ocean ridge crest juxtaposed against 80 m.y. oceanic lithosphere. The structure assumed for the mid-ocean ridge is $2.5 \mathrm{~km}$ of water, a $5-\mathrm{km}$ thick crust with a density (at $0^{\circ} \mathrm{C}$ ) of $2.8 \mathrm{~g} / \mathrm{cm}^{3}$ and an isothermal mantle at temperature $1333^{\circ} \mathrm{C}$. The $80 \mathrm{~m}$.y. oceanic lithosphere was modeled by the same $5 \mathrm{~km}$ thick crust and a lithosphere which has been thinned by a factor of 1.3. This initial geotherm is compared to that determined by allowing the model ridge crest to cool for $80 \mathrm{~m} . \mathrm{y}$. in Figure 15. The initial depth determined from this approximation is within $20 \mathrm{~m}$ of that of $80 \mathrm{~m} . \mathrm{y}$. old oceanic lithosphere and the difference decreases with time.

The present situation was modeled by calculating the temperature structure and water depths at a time $64 \mathrm{~m} . y$. (8 square root of time units) after the initial conditions. The calculated crustal depths across Chain Ridge are shown in Figure 16 and compared with three observed profiles. The model reproduces the general form of the basement and the abrupt increase in sediment thickness across Chain Ridge. The difference in the wavelength of the flexure on either side of the ridge is the result of the different lithospheric thermal structure. The effective elastic plate thickness $T_{e}$ at any location was determined by the local depth to the $450^{\circ} \mathrm{C}$ isotherm [Watts, 1978; Watts et al., 1980].

The lithospheric temperatures calculated for the model after 64 m.y. of cooling were used to determine densities for the gravity and geoid calculations. The average temperature was determined in three depth ranges for 64 m.y. old ocean, 144 m.y. old ocean and continental lithosphere. The continental lithosphere was assumed to have a linear temperature gradient (Figure 17). The temperatures were used to determine average densities in the depth ranges for each case assuming a coefficient of thermal expansion of $3.4 \times 10^{-5}{ }^{\circ} \mathrm{C}^{-1}$. The continental densities were used as a standard and subtracted from those determined for each region to produce the model shown in Figure 18. Gravity anomalies, geoid anomalies and deflection of the vertical were then calculated assuming a two dimensional structure and using the method of Talwani et al. [1959].

The calculated free-air gravity anomalies reproduce the form of the observed anomalies in the Northern Somali Basin (Figure 18). In particular, the model reproduces the large negative anomalies along the boundaries of the basin, the increase in gravity toward its center and the difference in the 


\section{DEFLECTION OF THE VERTICAL}

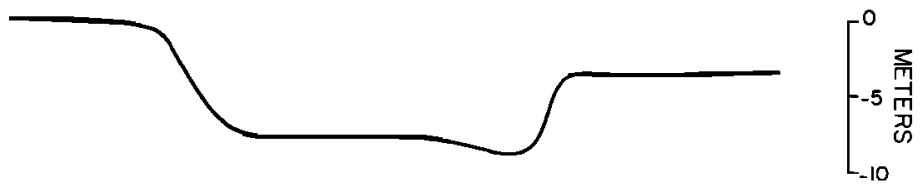

\section{GEOID ANOMALY}

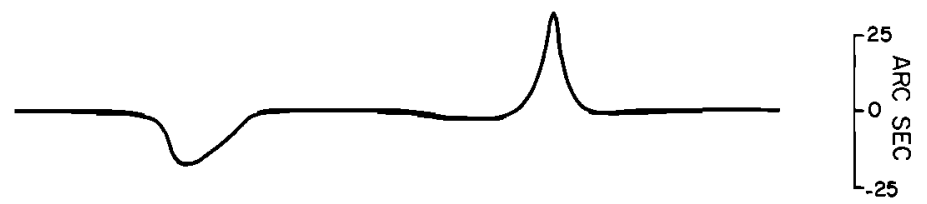

\section{GRAVITY ANOMALY}
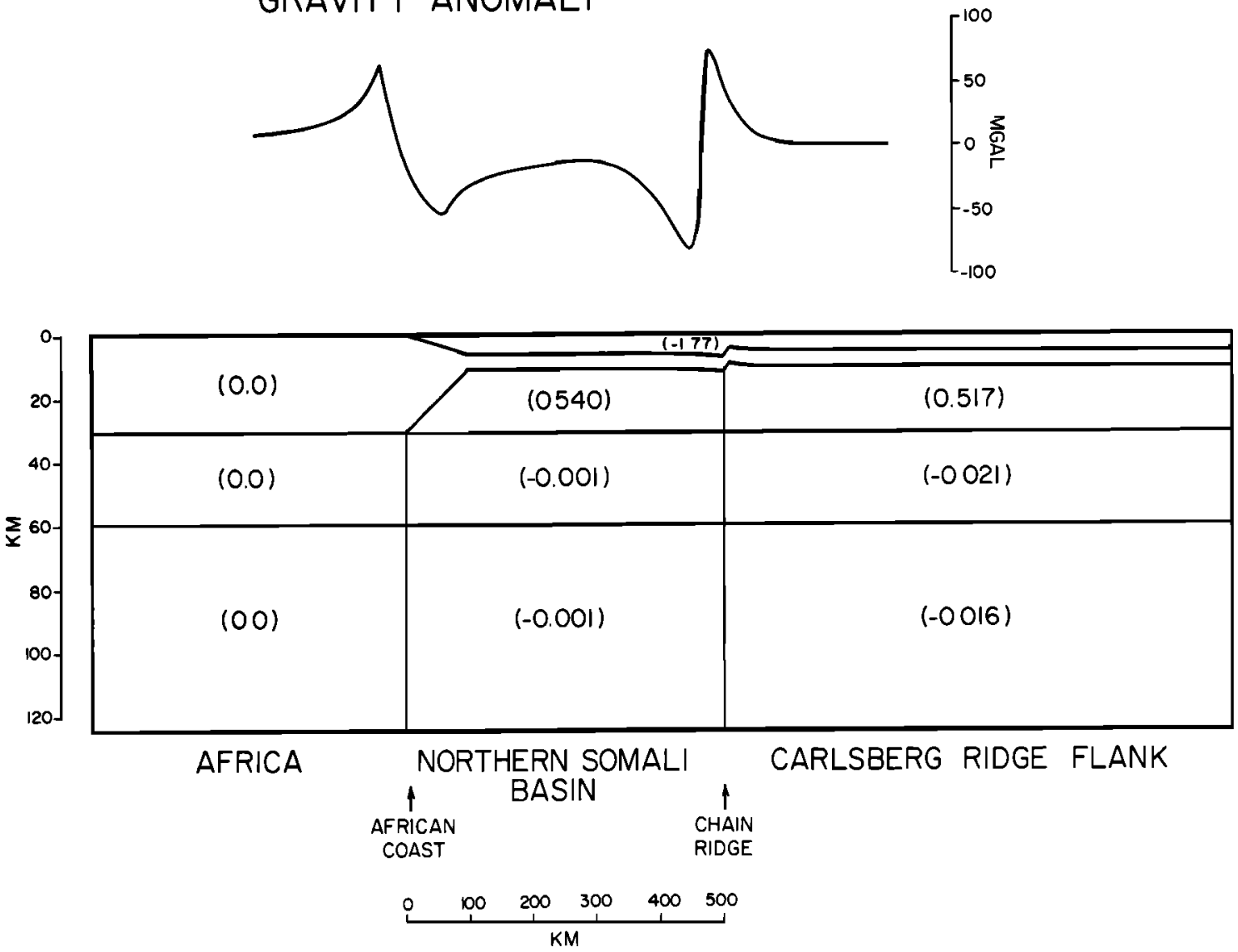

Fig 18. Free-air gravity anomalies, geoid anomalies and deflections of the vertical calculated from model shown at bottom of figure. Calculation assumes that bodies are two-dimensional and was done using the method of Talwani et al. [1959]. Densities were determined from Figure 16 and are referenced to continental lithosphere. Total mass of model is zero.

level of the gravity anomalies in the center of the Northern Somali Basin and outside the basin. The difference in level can be seen to result from the superposition of the continental margin edge effect and the fracture zone edge effect as a result of the relatively narrow width of the basin. Model gravity anomalies across Chain Ridge are compared with observed gravity profiles in Figure 19. The observed and model anomalies agree well in both amplitude and wavelength.
The calculated model geoid is compared with observed profiles in Figure 20. The model anomalies reproduce well both the amplitude and gradients associated with the geoid steps over the continental margin and across Chain Ridge. A feature that the model does not reproduce is the characteristic small geoid peak over Chain Ridge and the broad shallow low to the east. These features appear to be the result of lateral heat conduction across Chain Ridge, which was not included in the 


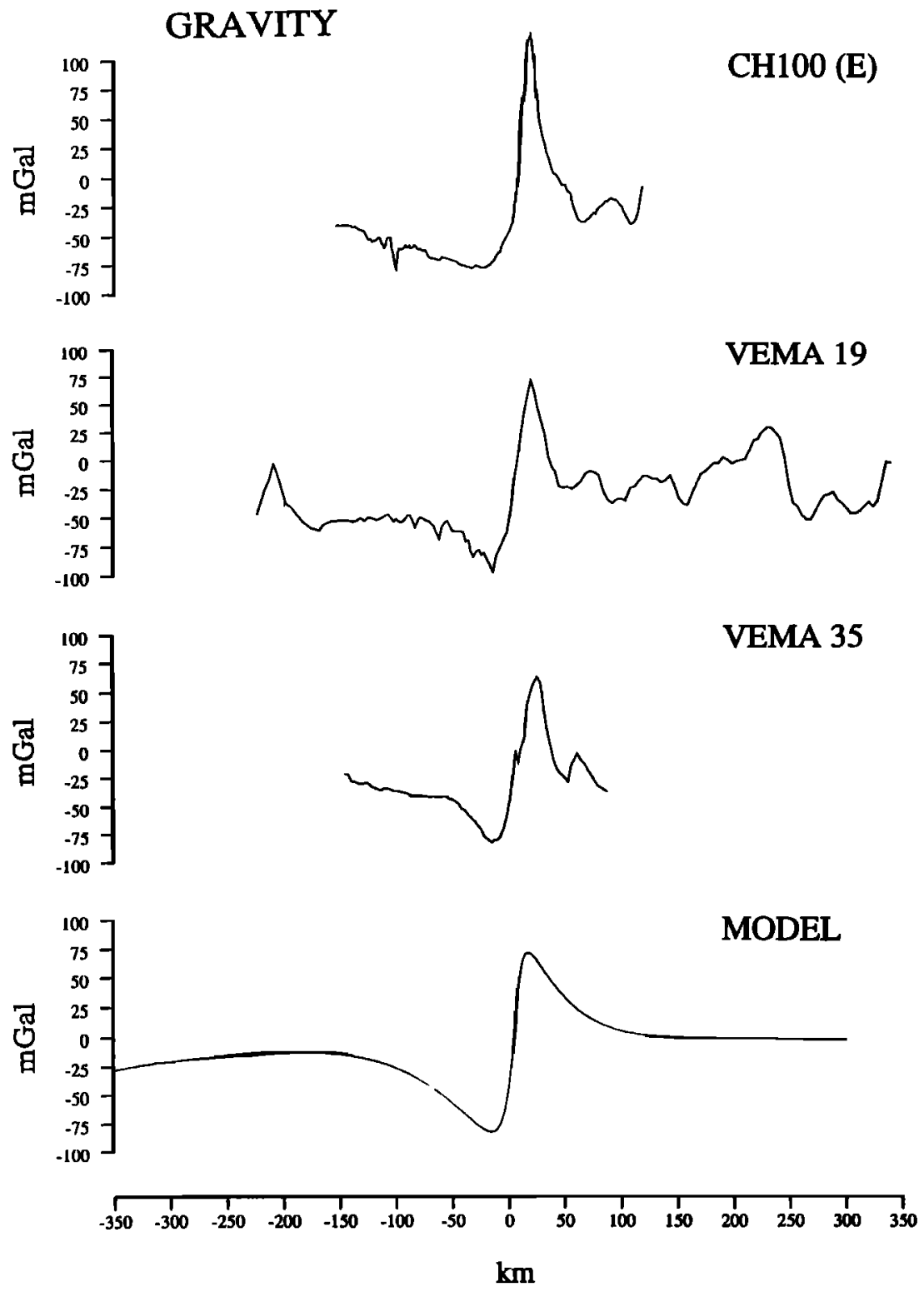

Fig 19. Free-air gravity anomalies across Chain Ridge for model shown in Figure 18 compared with three observed profiles. Location of profiles is shown in Figure 2a. Chain Ridge is at $0 \mathrm{~km}$ on horizontal scale. Profiles are projected along $\mathrm{N} 120^{\circ} \mathrm{E}$. East is to the right.

calculation because the resulting density gradient would be difficult to accurately quantify as input to the gravity and geoid calculation (Figure 18). Sandwell [1984] investigated the effects of lateral heat conduction and found that for a case where the fracture zone is "locked" against vertical slip, lateral heat flow does not reduce either the amplitude or gradient of the geoid step, but results in a broad shallow depression or side lobe such as is observed across Chain Ridge. The characteristic gravity and geoid anomalies associated with the Northern Somali Basin are thus the result of the superposition of edge effects associated with its boundaries.

\section{Conclusions and Summary}

1. The western margin of the Indian Ocean east of Africa is made up of a series of small oceanic basins connected by long north-south trending fracture zones. These basins formed during the Late Jurassic and Early Cretaceous as a result of motion between East and West Gondwanaland. The magnetic anomalies in the Western Somali Basin are reinterpreted as resulting from an east-west trending mid-ocean ridge, which was active by M22 time (Kimmeridgian) and died soon after M0 time (Aptian). The extinct ridge axis can be traced from the Davie Ridge fracture zone near the African margin at $8^{\circ} \mathrm{S}$, $41^{\circ} \mathrm{E}$ eastward with a number of small left-lateral offsets to a large fracture zone at $47^{\circ} \mathrm{E}$ where it is offset to $4^{\circ} \mathrm{S}$. It continues eastward to the Dhow fracture zone at $49^{\circ} \mathrm{E}$ where it appears to terminate (Figure 8).

2. The Davie Ridge fracture zone connects the West Somali Basin spreading center with a spreading center to the south in the Mozambique Basin which was active at the same time as the West Somali Basin ridge. The Dhow-VLCC-ARS fracture 

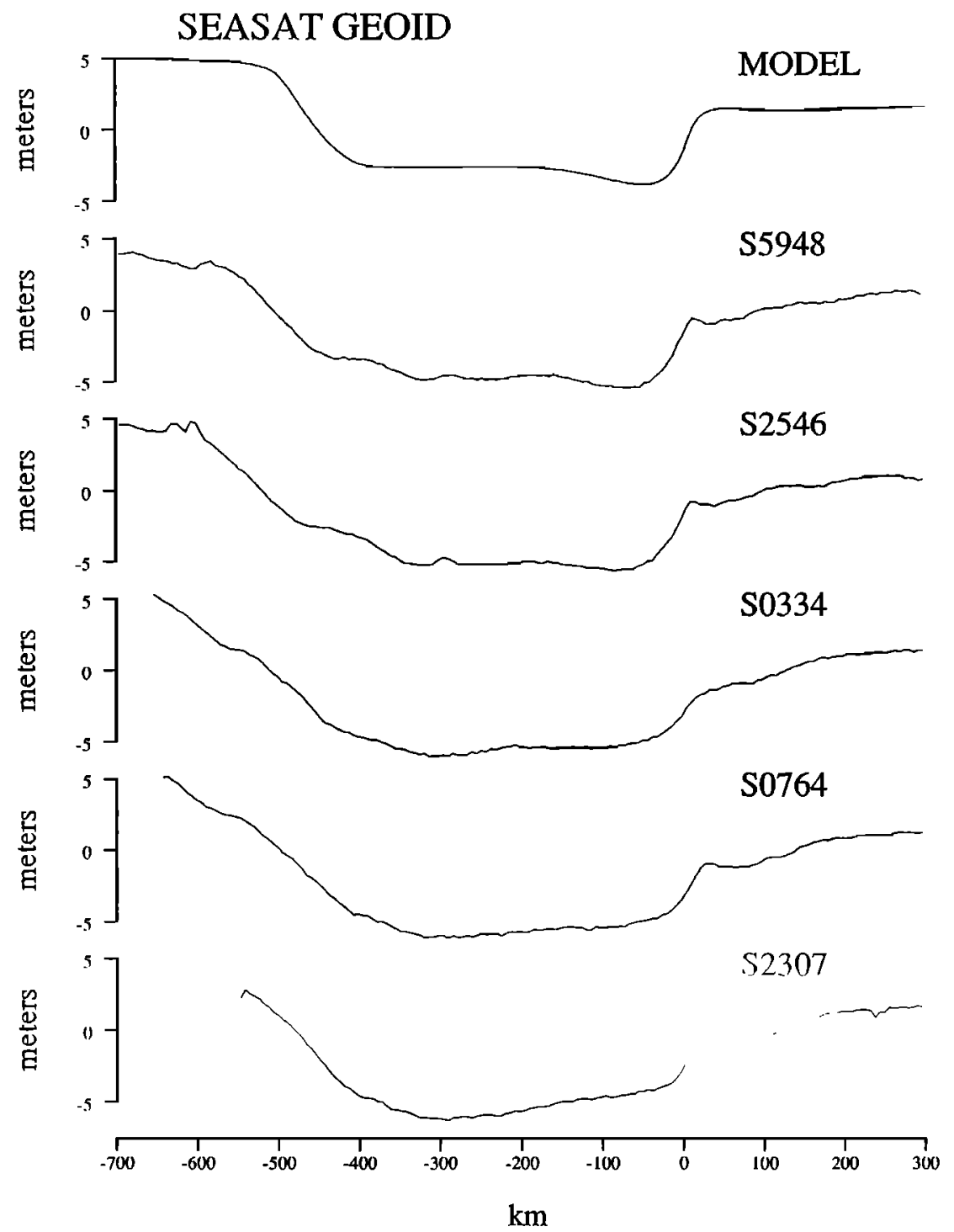

Fig 20. Geoid anomaly profile across the Northern Somali Basin for model shown in Figure 18 compared with observed SEASAT geoid profiles. Location of profiles is shown in Figure 4a. Chain Ridge is at $0 \mathrm{~km}$ on horizontal scale. All profiles are projected along $N 120^{\circ} \mathrm{E}$. East is to the right.

zone complex can be shown to continue north of the $4^{\circ} \mathrm{N}$ bathymetric high marking the boundary between the Western and Northern Somali Basins and to obliquely intersect the African continental margin near $7^{\circ} \mathrm{N}$ in the North Somali Basin. Chain Ridge continues south to $2^{\circ} \mathrm{N}$ nearly to the VLCC fracture zone (Figure 10). Chain Ridge is associated with a large regional change in basement depths with much deeper basement found to the northwest in the Northern Somali Basin. The area east of Chain Ridge is characterized by NW-SE trending Late Cretaceous and Tertiary magnetic anomalies [Schlich, 1982] and was created at the Carlsberg Ridge. There are magnetic anomalies in the Northern Somali Basin which appear to be east-west trending, but it has not been possible to identify them. The geometry of the tectonic elements (Figure 8) suggest that the Northern Somali Basin is the remnant of an ocean basin created in the Late Jurassic and Early Cretaceous as the third of a series of small basins separated by long fracture zones that resulted from the breakup of East and West Gondwanaland. The original Northern Somali Basin was split by the Late Cretaceous northward motion of India. Half of the basin was transported north with India and the remainder left as the present Northern Somali Basin. Chain Ridge marks the scar from this division and there is an approximately $80-m . y$. age discontinuity across Chain Ridge. The area west of the ARS fracture zone and north of the $4^{\circ} \mathrm{N}$ bathymetric high may represent extended continental crust.

3. The Northern Somali Basin is associated with distinctive geoid and gravity anomalies. The basin is characterized by a $5-m$ depression in the geoid with steep gradients associated with the boundaries of the basin. The gravity anomalies are also more negative than in surrounding areas and the boundaries of the basin are marked by large amplitude anomalies. In particular, a large negative gravity anomaly is found completely around the basin just inside it. Quantitative modeling shows that the geoid and gravity anomalies can both be explained as the superposition of edge effects resulting from the structure of the boundaries. Continental margin edge effects are present on the western and northern boundaries, and a fracture zone edge effect is present across Chain Ridge 
on the southeastern side of the basin. The form of the gravity and geoid anomalies across Chain Ridge implies that the depth offset has been "locked" and that differential subsidence has produced significant lithospheric flexure.

Acknowledgments. I would like to thank J.K. Weissel, M.S. Steckler and M.F. Coffin for constructive comments on the manuscript. This work was supported by Office of Naval Research contract N00014-C-0132 and by NASA grant NAG-5-881. Lamont Doherty contribution number 4322.

\section{REFERENCES}

Bergh, H.W. and I.O. Norton, Prince Edward fracture zone and the evolution of the Mozambique Ridge, J. Geophys. Res., 81, 5221-5239, 1976.

Bosellini, A., East African continental margins, Geology, 14, 76-78, 1986.

Bunce, E.T. and P. Molnar, Seismic reflection profiling and basement topography in the Somali Basin: possible fracture zones between Madagascar and Africa, $\mathrm{J}$. Geophy. Res.. 82, 5305-5311, 1977.

Bunce, E.T., C.O. Bowin and R.L. Chase, Preliminary results from the 1964 cruise of $R / V$ Chain to the Indian Ocean, Phil. Trans. Roy. Soc. London, Ser. A, 259, 218226, 1966.

Bunce, E.T., M.G. Langseth, R.L. Chase and M. Ewing, Structure of the Western Somali Basin, J. Geophys. Res., 72, 2547-2555, 1967.

Canadian Hydrographic Service, GEBCO (General Bathymetric Chart of the Oceans), Ottowa, Canada, 1975.

Cazenave, A., B. Lago and K. Dominh, Geoid anomalies over the northeast Pacific fracture zones from satellite altimeter data, Geophys. J. R. astr. Soc., 69, 15-31, 1982.

Cazenave, A., B. Lago and K. Dominh, Thermal parameters of the oceanic lithosphere estimated from geoid height data, J. Geophys. Res., 88, 1105-1118, 1983.

Cochran, J.R., The Gulf of Aden: Structure and evolution of a young ocean basin and continental margin, $J$. Geophys. Res., 86, 263-288, 1981.

Cochran, J.R., The magnetic quiet zone in the Eastern Gulf of Aden: Implications for the early development of the continental margin, Geophys. J. R. Astr. Soc., 68, 171201, 1982.

Cochran, J.R., Effects of finite rifting times on the development of sedimentary basins, Earth Planet Sci. Lettr., 66, 289-303, 1983.

Coffin, M.F., Evolution of the conjugate East AfricanMadagascar margins and the western Somali Basin, Ph.D. thesis, 336 pp., Columbia Univ., New York, 1985.

Coffin, M.F., P.D. Rabinowitz and R.E. Houtz,. Crustal structure in the western Somali Basin, Geophys. J.R. astr. Soc., 86, 331-369, 1986

Coffin, M.F. and P.D. Rabinowitz, Reconstruction of Madagascar and Africa: Evidence from the Davie fracture zone and Western Somali Basin, J. Geophys. Res., 92, 9385-9406, 1987.

Crough, S.T., Geoid anomalies across fracture zones and the thickness of the lithosphere, Earth Planet. Sci. Lett., 44, 224-230, 1979.

Detrick, R.S., An analysis of geoid anomalies across the Mendocino fracture zone: Implications for thermal models of the lithosphere, $J$. Geophys. Res. 86, 11751-11762, 1981.

Emerick, C.M. and R.A. Duncan, Age progressive volcanism in the Comores Archipelago, Western Indian Ocean and implications for Somali plate tectonics, Earth Planet. Sci. Lett., 60, 415-428, 1982.
Esson, J., M.F.J. Flower, D.F. Strong, B.G.J. Upton and W.J. Wadsworth, Geology of the Comores Archipelago, Western Indian Ocean, Geol. Mag, 107, 549-557, 1970.

Harland, W.B., A.V. Cox, P.G. Llewellyn, C.A.G. Pickton, A. G. Smith, and R. Walters, A Geologic Time Scale, 131 pp., Cambridge University Press, Cambridge, 1982.

Haxby, W.F. and D.L. Turcotte, On isostatic geoid anomalies, $J$. Geophys. Res., 83. 5473-5478, 1978.

Hey, R., Tectonic evolution of the Cocos-Nazca spreading center, Geol. Soc. Am. Bull., 88, 1404-1420, 1977.

Kent, D.V., and F.M. Gradstein, A Cretaceous and Jurassic geochronology, Geol. Soc. Am. Bull., 8, 1037-1049, 1977.

Kristoffersen, Y. and M. Talwani, Extinct triple junction south of Greenland and the Tertiary motion of Greenland relative to North America, Geol. Soc. Am. Bull., $\underline{88}$, 1037-1049, 1977.

Larson, R.L., and T.W.C. Hilde, A revised time scale of magnetic reversals for the Early Cretaceous and Late Jurassic, J. Geophys. Res., 80, 2586-2592, 1975.

Laughton, A.S., R.B. Whitmarsh and M.T. Jones, The evolution of the Gulf of Aden, Phil. Trans. Roy. Soc. London, Ser. A., 267, 227-266, 1970.

Louden, K.E. and D.W. Forsyth, Thermal conduction across fracture zones and the gravitational edge effect, $\mathrm{J}$. Geophys. Res., 81, 4869-4874, 1976.

Masson, D.G., Evolution of the Mascarene Basin, western Indian Ocean and the significance of the Amirante Arc, Mar. Geophys. Res., 6, 365-382, 1984.

Masson, D.G., R.B. Kidd, and R.G. Roberts, Late Cretaceous sediment sample from the Amirante Passage, western Indian Ocean, Geology, 10, 264-266, 1982.

Mauge, L.A., J. Segoufin, E. Vernier and C. Froget, Geomorphologie et origine des bancs du nord-est du canal de Mozambique-Ocean Indien Occidental, Mar. Geol., 47, $35-55,1982$.

McKenzie, D.P. and J.G. Sclater, The evolution of the Indian Ocean since the Late Cretaceous, Geophys. J. roy. Astron. Soc., 25, 437-528, 1971.

Norton, I.O., and J.G. Sclater, A model for the evolution and development of the Indian Ocean and the breakup of Gondwanaland, J. Geophys. Res., 84, 6803-6830, 1979.

Parson, L., D.G. Roberts and P. Miles, Magnetic anomalies in the Somali Basin, north-west Indian Ocean (abstract), Geophys. J. Roy. Astr. Soc. 65, 260, 1981.

Parsons, B. and J.G. Sclater, An analysis of ocean floor bathymetry and heat flow with age, J. Geophys. Res., $\underline{82}$, 803-827, 1977.

Rabinowitz, D.P., M.F. Coffin and D. Falvey, The Madagascar-Africa Separation, Science. 220, 67-69, 1983.

Rea, D.K., and B.T. Malfait, Geologic evolution of the Northern Nazca Plate, Geology, 2, 317-320, 1974.

Sandwell, D.T., Thermomechanical evolution of oceanic

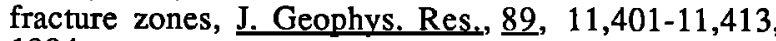
1984.

Sandwell, D.T., and G. Schubert, Geoid height versus age for symmetric spreading ridges, J. Geophys. Res., 85, 7325-7241, 1980

Sandwell, D.T. and G. Schubert, Geoid height-age relations from Seasat altimeter profiles across the Mendocino fracture zone, J. Geophys. Res., 87, 3949-3958, 1982a.

Sandwell, D.T. and G. Schubert, Lithospheric flexure at fracture zones, J. Geophys. Res., 87, 4657-4667, 1982b.

Schlich, R., The Indian Ocean: Aseismic Ridges, Spreading Centers and Oceanic Basins, in, The Ocean Basins and Margins, vol. 6, The Indian Ocean, edited by A.E.M. Nairn and F.G. Stehli, p. 51-148, Plunum, New York, 1982.

Schlich, R., F. Aubertin, J.R. Deteil, L. Leclaire, P. Magnier, L. Montadert, P. Patriat, and P. Valery, Données 
nouvelles sur le substratum du bassin de Somalie á partir d'un profil de sismique-réflexion, $\underline{C}$. R. Hebd. Seances Acad. Sci. Ser. D, 275, 1331-1334, 1972.

Scrutton, R.A., Davie fracture zone and the movement of Madagascar, Earth Planet. Sci. Lett., 39, 84-88, 1978.

Scrutton, R.A., W.B. Heptonstall and J.H. Peacock, Constraints on the motion of Madagascar with respect to Africa, Mar.Geol. 43, 1-20, 1981.

Ségoufin, J., Anomalies magnétiques mesozoiques dans le bassin de Mozambique, C. R. Hebd. Seances Acad. Sci., Ser. D, 287, 109-112, 1978.

Ségoufin, J. and P. Patriat, Existence d'anomalies mésozoiques dans le bassin de Somalie. Implications pour les relations Afrique-Antarctique-Madagascar, C. R. Hebd. Seances Acad. Sci., Ser. D, 291, 85-88, 1980.

Shipboard Scientific Party, Site 234, Initial Rep. Deep Sea Drill, Proj., 24, 249-282, 1974a.

Shipboard Scientific Party, Site 240, Initial Rep. Deep Sea Drill. Proj. 25, 64-86, 1974b.

Simpson, E.S.W., J.G. Sclater, B. Parsons, I. Norton and L. Meinke, Mesozoic magnetic lineations in the Mozambique Basin, Earth Planet. Sci. Lett., 43, 260-264, 1979.

Steckler, M.S., The thermal and mechanical evolution of Atlantic-type continental margins, Ph.D. Thesis, 261 p, Columbia Univ., New York, 1981.

Stein, C.A., and J.R. Cochran, The transition between Sheba Ridge and Owen Basin: Rifting of old oceanic lithosphere, Geophys. Jour. Roy. Astr. Soc. 81, 47-74, 1985.
Talwani, M. and O. Eldholm, Evolution of the NorwegianGreenland Sea, Geol. Soc. Am. Bull., 88, 969-999, 1977.

Talwani, M., J.L. Worzel, and M. Landisman, Rapid gravity computations for two-dimensional bodies with application to the Mendocino submarine fracture zone, J. Geophys. Res., 64, 49-59, 1959.

Watts, A.B., An analysis of isostasy in the world's oceans, 1, Hawaiian-Emperor Seamount Chain, J. Geophys. Res., 83, 5989-6004, 1978.

Watts, A.B., Gravity anomalies over oceanic rifts, in, Continental and Oceanic Rifts, Geodyn. Ser., vol. 8, edited by G. Palmason, pp. 99-105, AGU, Washington, D.C., 1982.

Watts, A.B., J.H. Bodine and M.S. Steckler, Observations of flexure and the state of stress in the oceanic lithosphere, J. Geophys. Res., 85, 6369-6376, 1980.

Weissel, J.K. and A.B. Watts, Tectonic evolution of the Coral Sea Basin, J. Geophys. Res., 84, 4572-4582, 1979.

J.R. Cochran, Lamont-Doherty Geological Observatory, Palisades, NY, 10964.

(Received June 29,1987;

revised April 7,1988;

accepted April 9,1988.) 


\section{Correction to "Somali Basin, Chain Ridge, and Origin of the Northern Somali Basin Gravity and Geoid Low" by James R. Cochran}

In the paper "Somali Basin, Chain Ridge, and Origin of the Northern Somali Basin Gravity and Geoid Low" by James R. Cochran (Journal of Geophysical Research, 93(B10), 11,985-12,008, 1988), an incorrect version of Figure 18 was published in which the curves for the "deflection of the vertical" and the "geoid anomaly" were switched. The correct version is presented here.

DEFLECTION OF THE VERTICAL

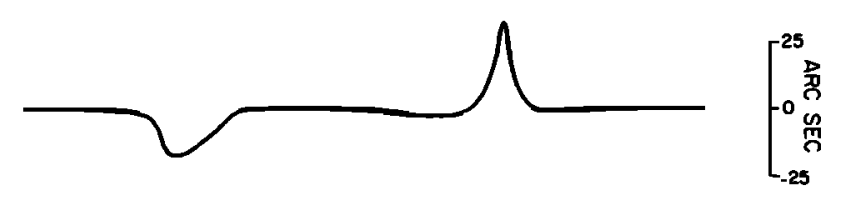

GEOID ANOMALY

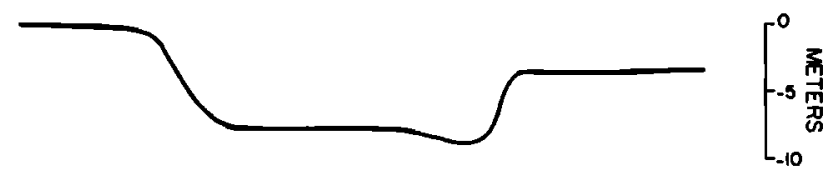

GRAVITY ANOMALY
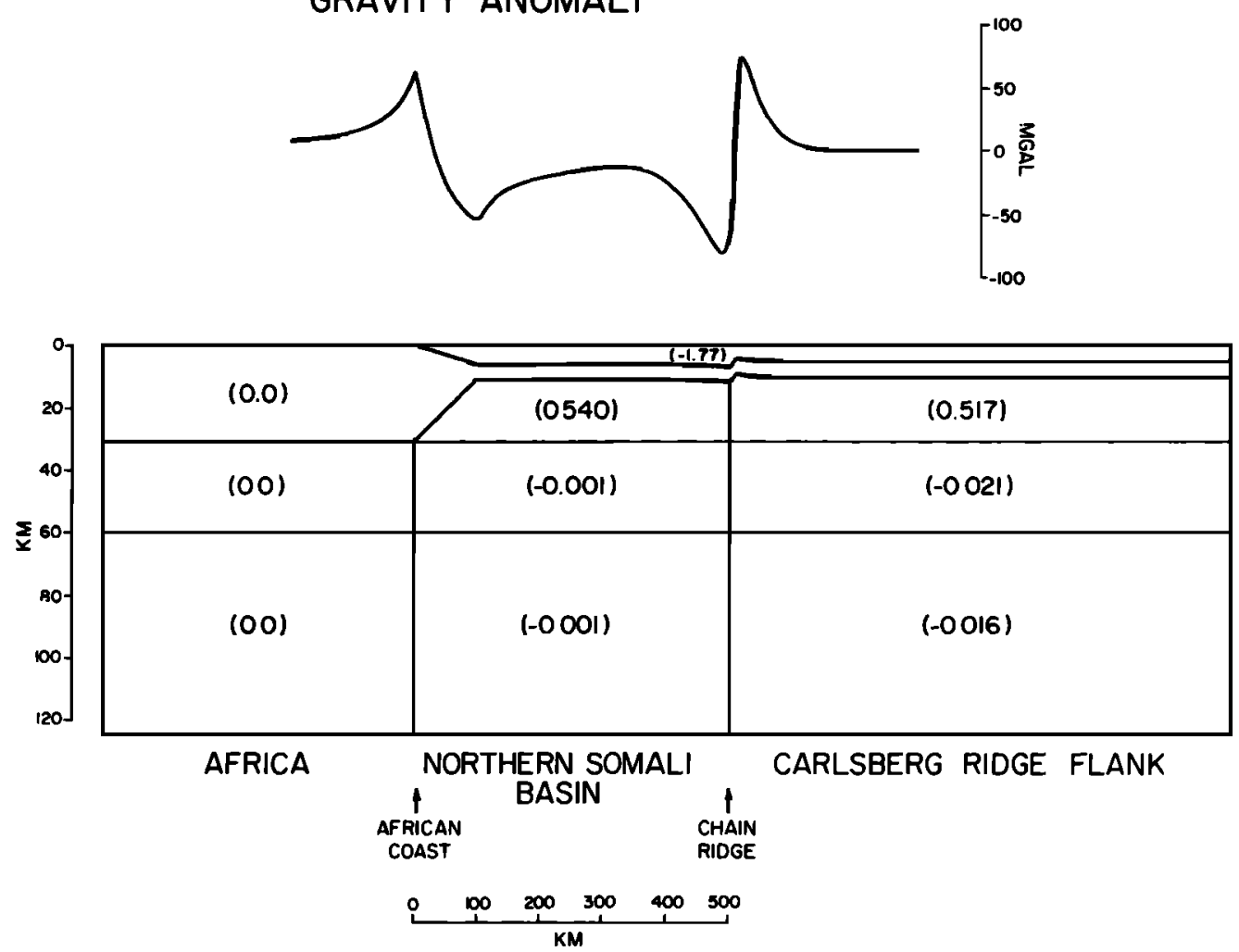

Fig. 18. Free-air gravity anomaljes, geoid anomalies and deflections of the vertical calculated from model shown at bottom of figure. Calculation assumes that bodies are two-dimensional and was done using the method of Talwani et al. [1959]. Densities were determined from Figure 16 and are referenced to continental lithosphere. Total mass of model is zero.

(Received October 17, 1988.)

Copyright 1988 by the American Geophysical Union. 